\title{
LA JOLLA NATURAL RADIOCARBON MEASUREMENTS $X$
}

\author{
T W LINICK*
}

Mt Soledad Radiocarbon Laboratory, University of California, San Diego La Jolla, California 92093

\section{INTRODUCTION}

The following date list covers samples dated by the La Jolla (Mt Soledad) Radiocarbon Laboratory from January 1979 through August 1982. Most archaeologic, most geologic, and some geochemical samples measured during that period are included here. Results of ${ }^{14} \mathrm{C}$ analyses of samples of tree rings, banded coral rings, and Antarctic seawater dissolved inorganic carbon measured during this period will be published elsewhere. Because of the cessation of all federal grant funding of this laboratory, this is the last date list to be published by it.

Sample preparation methods have remained the same as described by Linick (1977). Seven gas proportional counters described previously by Linick $(1977 ; 1979)$ and a $0.2 \mathrm{~L}$ copper counter were used. As previously, results reported here are based on $95 \%$ of NBS oxalic acid activity normalized to a $\delta^{13} \mathrm{C}$ of $-19 \%$ (PDB). All sample activities have been normalized to a $\delta^{13} \mathrm{C}$ of $-25 \%$ (PDB). Measured $\delta^{13} \mathrm{C}$ values are given for all samples for which the measurement was made; the mass spectrometric analyses were performed on $\mathrm{CO}_{2}$ prepared by complete recombustion of an aliquot of the acetylene counting gas sample except for the small number of cases in which $\mathrm{CO}_{2}$ was counted. Ages listed are conventional radiocarbon ages based on the 5568-year Libby ${ }^{14} \mathrm{C}$ half-life; listed uncertainties are one sigma statistical standard errors. Conventional ages for shells and carbonate sediments must be considered to be "apparent ages" only (Linick, 1979); estimated reservoir ages must be subtracted from them for proper interpretation. Where applicable, "calibrated" dates corresponding to the probable time of origin of terrestrial plant or animal organic material are given at the end of the sample descriptions. The estimated most probable date or range of dates is given, followed in parentheses by the range of dates corresponding to the $95 \%$ confidence interval. For the AD period, both the most probable date(s) and the $95 \%$ confidence interval were determined from Stuiver (1982, fig 3). For the BC period, the most probable date(s) were determined from Suess (1979, table 1) and from unpublished measurements by the La Jolla laboratory; for the BC period, the $95 \%$ confidence interval was determined from Klein et al (1982, table 2). $\Delta$ values have been age-corrected from the year of collection or growth to 1950 .

\section{ACKNOWLEDGMENTS}

Measurements by the La Jolla Radiocarbon Laboratory were financed by US National Science Foundation grants, including BNS79-15335 and ATM79-19866, with H E Suess as Principal Investigator. Additional funds enabling preparation of this paper were received from the California

* Present address: Laboratory of Isotope Geochemistry, Department of Geosciences, University of Arizona, Tucson, Arizona 85721 
Space Institute. Samples were prepared by S M Griffin, C S Hutto, and T L Jackson. S M Griffin, C S Hutto, and E M Druffel assisted in measuring the samples. D K Sullivan maintained the electronic equipment.

\section{ARCHAEOLOGIC SAMPLES}

\section{United States}

Most samples are from the Pacific coast. Listings are ordered from north to south.

Oregon

\section{LJ-5646. Manzanita}

$$
\text { Est } \delta^{13} C=-25.0 \%
$$

Beeswax probably assoc with shipwreck at beach at Manzanita $\left(45^{\circ}\right.$ $43^{\prime} \mathrm{N}, 123^{\circ} 57^{\prime} \mathrm{W}$ ). Specimen removed from center of larger sample stored since ca AD 1900 in mus colln. No known treatment of specimen. Coll ca 1900; subm by J A Woodward, Mt Hood Comm Coll, Gresham, Oregon. Comment (JAW): shipwreck thought to be from 16th, 17th, or early 18 th century AD. Calibration: AD 1540, 1630 (1490 to 1650).

\section{LJ-5267. Nehalem Bay}

$380 \pm 60$

Wood splints from woven mat from underwater site at Nehalem Bay, Tillamook Co $\left(45^{\circ} 42^{\prime} \mathrm{N}, 123^{\circ} 55^{\prime} \mathrm{W}\right)$. Found ca $2 \mathrm{~m}$ below mean tide level, under $50 \mathrm{~cm}$ of fine silt. From aboriginal fish weir (?) of Late Prehistoric or Historic period. Wood id by Center for Wood Anatomy Research as Western Larch (Larix occidentalis) or Douglas Fir (Pseudotsugu menziesii). Coll July 1980 and subm by J A Woodward. Comment (JAW): dating of aboriginal construction of weir is relevant to reconstruction of sea level and local environmental changes in Nehalem Bay during last 2000 yr. Calibration: AD 1470 (1420 to 1640$)$.

\section{LJ-5300. Nehalem Bay}

$260 \pm 40$

$\delta^{13} C=-26.6 \%$

Charcoal from Indian midden found below high tide level in Nehalem Bay $\left(45^{\circ} 42^{\prime} \mathrm{N}, 123^{\circ} 55^{\prime} \mathrm{W}\right)$. Coll Sept 1980 and subm by J A Woodward. Dated to reconstruct environmental changes in Nehalem Bay in last 500 yr. Calibration: AD 1640 (1500 to 1670,1740 to 1800$)$.

\section{LJ-5119. Gladstone}

$1510 \pm 40$

$\delta^{13} \mathrm{C}=-25.3 \%$ o

Charcoal from Clackamas Village Proj, Oregon State Univ site 35CL32, Gladstone $\left(45^{\circ} 22^{\prime} \mathrm{N}, 122^{\circ} 35^{\prime} \mathrm{W}\right)$. From undisturbed midden, Test Pit 1, Feature 1, $1 \mathrm{~m}$ depth from surface. Dated to establish historic or prehistoric phase identification of recently-relocated archaeol site in city of Gladstone. Coll Nov 1979 and subm by J A Woodward. Calibration: AD 550 (430 to 650$)$.

\section{California}

\section{Fort Irwin series}

Fragmented charcoal from Fort Irwin, on Drinkwater Lake, San Ber- 
nardino Co. Coll Jan 1981 and subm by R H Norwood, Regional Environmental Consultants, San Diego.

\section{LJ-5499. Fort Irwin, SBr-4446}

$$
\begin{array}{r}
\mathbf{2 2 0} \pm \mathbf{5 0} \\
\delta^{13} C=-14.5 \% 0
\end{array}
$$

Charcoal fragments from Site SBr-4446, N shore of Drinkwater Lake, Fort Irwin $\left(35^{\circ} 29^{\prime} 30^{\prime \prime} \mathrm{N}, 116^{\circ} 31^{\prime} 30^{\prime \prime} \mathrm{W}\right)$. From Unit E1-N0, 0 to $10 \mathrm{~cm}$ depth. Site is small camp with ca 30 flakes, metates, burned animal bone; shallow deposit to ca $10 \mathrm{~cm}$ depth. Calibration: AD 1660 (1530 to 1690 , 1720 to 1810,1920 to 1950$)$.

\section{LJ-5500. Fort Irwin, SBr-4449}

$1540 \pm 70$ $\mathrm{N}, 116^{\circ} 32^{\prime} 00^{\prime \prime} \mathrm{W}$ ), from Unit 11,60 to $70 \mathrm{~cm}$ depth. Site consists of surface scatters of ca $5600 \mathrm{~m}^{2}$ and $300 \mathrm{~m}^{2}$ areas of developed midden near granitic bedrock overhangs. Based on artifact types, sample was expected to date no older than AD 450. Calibration: AD 540 (340 to 650).

\section{LJ-5501. Fort Irwin, SBr-4449}

$1040 \pm 50$ depth. Comment (RHN): ${ }^{14} \mathrm{C}$ date serves as calibration for obsidian hydration rate, for dating Anasazi contact in region, for temporal context for $\mathrm{mt}$ base exploration, and for diversity of artifact types. Calibration: AD 990 (880 to 1040,1090 to 1150$)$.

\section{Tustin Plain series}

Three shell samples from Site CA-Ora-508, on Tustin Plain, near Upper Newport Bay, City of Irvine, Orange Co $\left(33^{\circ} 41^{\prime} \mathrm{N}, 117^{\circ} 50^{\prime} \mathrm{W}\right)$. Coll Sept 1978 by L Allen; subm by Adella Schroth, Archaeol Resource Management Corp, Garden Grove. Measured to determine temporal placement of site within Upper Newport series.

\section{LJ-4810. Tustin Plain, 34-64cm}

$\mathbf{1 9 0 0} \pm \mathbf{5 0}$

Shells (Chione sp) from Loc C, Test Unit 2, 34 to $64 \mathrm{~cm}$ depth.

$\delta^{13} \mathrm{C}=+0.7 \%$ c

\section{LJ-4812. Tustin Plain, 60-70cm \\ $2480 \pm 70$}

$=+1.4 \%$ depth.

Shells (Aequipecten circularis) from Loc AB, Test Unit 2, 60 to $70 \mathrm{~cm}$

\section{LJ-4811. Tustin Plain, 70-80cm}

$2640 \pm 70$ depth.

\section{Newland House series}

Samples from Newland House site, CA-Ora-183, on bluff above Santa Ana R basin, Huntington Beach, Orange Co $\left(33^{\circ} 40^{\prime} 33^{\prime \prime} \mathrm{N}, 117^{\circ} 59^{\prime} 10^{\prime \prime}\right.$ W). From Test Unit No. 14, Level 5, 50 to $60 \mathrm{~cm}$ depth, in immediate assoc with cogstone. Coll Aug 1979 by Joyce Clevenger, Johann Anderson, 
and Steven Goerke; subm by Constance Cameron, Anthropol Mus, California State Univ, Fullerton. Comment (CC): samples analyzed to date cogstone. First cogstone found in immediate assoc with datable material. Samples were of primary importance in delineating Orange Co chronology.

\section{LJ-4999. Newland House, charcoal}

$13,900 \pm 500$

Charcoal Comment: age was far greater than expected; thus there some question whether sample might have been contaminated with ${ }^{14} \mathrm{C}$ free asphaltic material (see Venkatesan et al, 1982).

\section{LJ-5002. Newland House, shell}

$5090 \pm 100$

Whole and fragmented shell (Chione).

\section{LJ-4813. Upper Newport Canyon}

$$
\delta^{13} C=+0.6 \%
$$

$1230 \pm 60$

Shells (Chione) from Site CA-Ora-287, on crest (alt $12.3 \mathrm{~m}$ ) of knoll at NW extremity of Upper Newport Canyon, Orange Co $\left(33^{\circ} 40^{\prime} \mathrm{N}\right.$, $117^{\circ} 51^{\prime} \mathrm{W}$ ). From Test Unit 1,30 to $40 \mathrm{~cm}$ level. Coll Nov 1978 and subm by Adella Schroth. Measured to determine temporal placement of site within Upper Newport series.

\section{LJ-4867. Upper Oso Drainage}

$820 \pm 90$

$\delta^{13} C=-25.5 \%$

Charcoal from Site CA-Ora-727, in Upper Oso Drainage, Orange Co $\left(33^{\circ} 39^{\prime} 00^{\prime \prime} \mathrm{N}, 117^{\circ} 37^{\prime} 30^{\prime \prime} \mathrm{W}\right)$, from 30 to $50 \mathrm{~cm}$ depth. Coll July 1979 and subm by J L Craib, Archaeol Resource Management Corp. Comment (JLC): sample dated to further define chronol ordering of early-late period in Mission Viejo environs. Date helps analyze contemporaneous site types in terms of general settlement system. Calibration: AD 1240 (1000 to $1320,1370$ to 1380$)$.

\section{Sand Canyon Wash series}

Samples from Site CA-Ora-379 in Sand Canyon Wash, San Joaquin Hills, Orange Co $\left(33^{\circ} 38^{\prime} 52^{\prime \prime} \mathrm{N}, 117^{\circ} 47^{\prime} 54^{\prime \prime} \mathrm{W}\right)$, alt 76 to $84 \mathrm{~m}$. Sand Canyon Wash (in $\mathbf{N}$ portion of San Joaquin Hills) drains from $\mathbf{N}$ to $\mathrm{S}$ until it reaches Tustin floodplain area, where it turns $\mathrm{W}$ to eventually join San Diego Creek, a major tributary of Upper Newport Bay. It is ca $6.4 \mathrm{~km}$ from mouth of wash to present Upper Newport Bay. Coll Sept 1979 and subm by R D Douglas, Larry Seeman Assocs, Inc (formerly Archaeol Planning Collaborative), Newport Beach.

\section{LJ-5117. Sand Canyon Wash, charcoal}

$$
\begin{array}{r}
\mathbf{2 4 0} \pm \mathbf{4 0} \\
\delta^{13} C=-26.1 \% \text { o }
\end{array}
$$

Charcoal from Rockshelter No. 1, TT5, 40cm depth. Calibration: AD 1650 (1530 to 1690,1730 to 1810,1940 to 1950$)$.

\section{LJ-5118. Sand Canyon Wash, shell}

$1610 \pm 40$

Shell (Aequipecten circularis) from open midden loc at habitation site, Unit 6,40 to $50 \mathrm{~cm}$ depth. 


\section{Coyote Canyon series}

Samples from fire hearth features at small Late Prehistoric campsite, CA-Ora-227, Coyote Canyon drainage of San Joaquin Hills region near city of Irvine, Orange Co $\left(33^{\circ} 37^{\prime} 22^{\prime \prime} \mathrm{N}, 117^{\circ} 49^{\prime} 50^{\prime \prime} \mathrm{W}\right)$. Site is ca $6.5 \mathrm{~km}$ $\mathrm{N}$ of Pacific Ocean and $4.8 \mathrm{~km} \mathrm{E}$ of Upper Newport Bay at alt $109 \mathrm{~m}$ on S-facing slope of small tributary drainage of Coyote Canyon. Prior to excavation, site consisted of small, oval-shaped shell midden, ca $384 \mathrm{~m}^{2}$. Ca $5 \%$ of surface area of midden deposit was excavated before site was destroyed during expansion of Coyote Canyon Landfill Facility. Coll Aug 1979 and subm by R D Douglas.

\section{LJ-4997. Coyote Canyon, charcoal, Unit $8 \quad \delta^{1 s} C=-25.2 \%$}

Charcoal from Unit 8 , Feature $4,20 \mathrm{~cm}$ below ground level. Calibration: AD 1650 (1500 to 1690,1720 to 1810,1930 to 1950$)$.

LJ-4998. Coyote Canyon, charcoal, Unit $2 \quad \begin{array}{r}\mathbf{2 3 0} \pm \mathbf{6 0} \\ \boldsymbol{\delta}^{13} C=-25.2 \% 0\end{array}$

Charcoal from Unit 2, Feature $1,15 \mathrm{~cm}$ below ground level. Comment: previous measurements for charcoal samples from fire hearth feature in Unit 2 at same site are $230 \pm 70$ for 10 to $20 \mathrm{~cm}$ below ground level and $330 \pm 70$ for 30 to $40 \mathrm{~cm}$ below ground level (LJ-4254 and -4255 , respectively: R, 1980, v 22, p 1035). Comment (RDD): results for all charcoal at site suggest that site was occupied after AD 1500. Date is important for understanding of aboriginal cultural patterns of period just prior to European contact in coastal Southern California. Calibration: AD 1650 (1490 to 1880,1920 to 1950$)$.

\section{LJ-5000. Coyote Canyon, shell, Unit 7 Shell (Ostrea lurida) from Unit 7, 10 to $20 \mathrm{~cm}$ below ground level.}

$1320 \pm 40$

\section{LJ-5001. Coyote Canyon, shell, Unit 8}

$$
\begin{array}{r}
\mathbf{8 9 0} \pm \mathbf{5 0} \\
\delta^{1 s} C=+1.3 \%
\end{array}
$$

Shell (Chione undatella) from Unit 8,10 to $20 \mathrm{~cm}$ below ground level. Comment: charcoal sample LJ-4997, above, and this shell sample came from essentially same provenience. Shell sample appears to be $650 \pm 70 \mathrm{yr}$ older $\left({ }^{14} \mathrm{C}\right.$ depletion of $8 \pm 1 \%$ ), somewhat larger than usual marine reservoir effect in area.

\section{Laguna Beach series}

Nine shell samples from coastal sites in and near Laguna Beach, Orange Co. Coll and subm by N M Magalousis, Chapman Coll, Orange. Comment (NMM): samples dated to establish basis for more acceptable and realistic chronology for Laguna Beach area. Some samples may qualify for National Registry status. Ages were expected to range between 3000 and 9000 BP. Only two Laguna Beach sites dated previously ("Laguna Woman" site and Site CA-Ora-370). Samples related directly to gap in recent known dates and "Laguna Woman" find. For Crescent Bay sites, aim was to date change of subsistence levels at site from period of over-extrac- 
tion of food from local estuary to period of definitive decrease of shell size, types, and volume. Comment: ages for shells from Site Ora-370, rock shelter in Sycamore Hills area of Laguna Beach $\left(33^{\circ} 33^{\prime} \mathrm{N}, 117^{\circ} 46^{\prime} \mathrm{W}\right)$, are $810 \pm 50$ and $1310 \pm 40$ (LJ-3449 and -3515 , respectively: R, 1979, v 21, p 187).

\section{LJ-4878. Crescent Bay}

$$
4400 \pm 90
$$

Shell fragments from Site $\left(33^{\circ} 32.7^{\prime} \mathrm{N}, 117^{\circ} 481^{\prime} \mathrm{W}\right)$. Site found in Launa Beach. From Sounding clift site, first prehistoric shelter depth. Coll Sept 1978.

\section{LJ-4879. Crescent Bay}

$$
\begin{array}{r}
5040 \pm 90 \\
\delta^{13} C=+1.2 \% o
\end{array}
$$

Shell fragments from Site CA-Ora-596 (see LJ-4878, above). From Sounding 1, Loc C, Level 7, 70 to 80cm depth. Coll Sept 1978.

\section{LJ-5292. Crescent Bay Park \# 1}

$\mathbf{5 5 8 0} \pm \mathbf{8 0}$

Shells from Crescent Bay Park site, on cliff edge overlooking Pacific Ocean, Laguna Beach $\left(33^{\circ} 32.7^{\prime} \mathrm{N}, 117^{\circ} 48.1^{\prime} \mathrm{W}\right)$. This is portion of village site of major importance. From Test Pit 3, Level 3, 34cm depth. Coll July 1979.

LJ-5293. Crescent Bay Park \#2

$\mathbf{5 1 4 0} \pm \mathbf{6 0}$

Shells from Crescent Bay Park site (see LJ-5292, above). From Sounding 1, Loc B, center, Level 6. Coll Apr 1979.

\section{LJ-5294. Crescent Bay Park \#3}

$5090 \pm 100$

Shells from Crescent Bay Park site (see L J-5292, above). From Sounding 1, Loc D, Level 6, Feature 3. Coll Apr 1979.

\section{LJ-5295. Crescent Bay Park \#4}

$\mathbf{5 0 4 0} \pm \mathbf{6 0}$

Shells from Crescent Bay Park site (see LJ-5292, above). From Sounding 1, Loc D, Level 5. Coll Apr 1979.

\section{LJ-5296. Dolley \# 1}

$2610 \pm 70$

Shells from Dolley site, coastal site on cliff edge next to Pacific Ocean, South Laguna Beach $\left(33^{\circ} 30^{\prime} \mathrm{N}, 117^{\circ} 45^{\prime} \mathrm{W}\right)$. From Test Pit 5, E corner of Dolley property, Level 3, 39cm depth. Coll June 1979.

\section{LJ-5297. Fowlie \# 1}

$$
\begin{array}{r}
4620 \pm 60 \\
\delta^{13} C=+2.0 \% \text { o }
\end{array}
$$

Fragmented, crumbly shells from Fowlie site, hunting site in San Joaquin Hills, ca $400 \mathrm{~m}$ from Pacific Ocean, South Laguna Beach $\left(33^{\circ} 30^{\prime \prime} \mathrm{N}\right.$, $\left.117^{\circ} 45^{\prime} \mathrm{W}\right)$. From Test Pit 5, Level 3, 30 to 40 cm depth. Coll June 1979. 
LJ-5298. Fowlie \#2

$\delta^{13} C=+2.2 \%$ o

Shells from Fowlie site (see LJ-5297, above). From Test Pit 2, Level 1, Feature 1, 10cm depth. Coll June 1979.

\section{San Dieguito River Valley series}

Ten shell samples coll from S side of San Dieguito River Valley, E of Camino Real, city of Del Mar, San Diego Co. Coll and subm by R H Norwood. Measured to date occupation of sites by La Jolla Indian culture.

\section{LJ-4608. SDM-W-40 West}

$3930 \pm 80$

Shells from Site SDM-W-40 West, $\mathrm{E}$ of and adjacent to El Camino Real $\left(33^{\circ} 13^{\prime} 50^{\prime \prime} \mathrm{N}, 117^{\circ} 58^{\prime} 22.2^{\prime \prime} \mathrm{W}\right)$. From Unit E104/N100, 30 to 40cm depth at W-40 West loc. Coll Aug 1978.

\section{LJ-4609. SDM-W-40}

$$
8650 \pm 110
$$

Shells (Pecten) from Site SDM-W-40, "La Jolla" site on knoll on S side of San Dieguito R ( $\left.33^{\circ} 13^{\prime} 44^{\prime \prime} \mathrm{N}, 117^{\circ} 58^{\prime} 24.3^{\prime \prime} \mathrm{W}\right)$. From shell lens in Unit E89/N87, 40 to $50 \mathrm{~cm}$ depth. Coll Aug 1978. Dated to refine chronology of La Jolla climax in area.

\section{LJ-4610. SDM-W-1584}

$$
8450 \pm 180
$$

Shells (Chione) from Site SDM-W-1584, "La Jolla" site on knoll overlooking Gonzalez Canyon to $\mathrm{S}\left(33^{\circ} 13^{\prime} 37.5^{\prime \prime} \mathrm{N}, 117^{\circ} 58^{\prime} 18.1^{\prime \prime} \mathrm{W}\right)$. From Unit E110/N100, 40 to $50 \mathrm{~cm}$ depth. Coll Aug 1978. Expected to date probable second and later occupation of site.

\section{LJ-4611. SDM-W-1584}

$$
8030 \pm 100
$$
Unit E112/N91, 80 to $90 \mathrm{~cm}$ depth. Coll Sept 1978. Dates lower occupation of probable two-component La Jolla site.

\section{LJ-4612. SDM-W-1585}

$7400 \pm 100$

Shells (Chione) from Site SDM-W-1585, La Jolla site on knoll overlooking San Dieguito R to N (33 $\left.13^{\circ} 30^{\prime \prime} \mathrm{N}, 117^{\circ} 58^{\prime} 23.8^{\prime \prime} \mathrm{W}\right)$. From 20 to $30 \mathrm{~cm}$ depth. Coll July 1978.

\section{LJ-4613. SDM-W-1585}

$8420 \pm 100$

Shells (Pecten) from Site SDM-W-1585 (see LJ-4612, above). From Unit E101/N78, 30 to 40cm depth. Coll July 1978.

\section{LJ-4614. SDM-W-1586}

$$
8600 \pm 110
$$

Shells (Pecten) from Site SDM-W-1586 (SDi-194), La Jolla site on high knoll overlooking San Dieguito R to N $\left(33^{\circ} 13^{\prime} 10.4^{\prime \prime} \mathrm{N}, 117^{\circ} 58^{\prime} 20.8^{\prime \prime}\right.$ W). From Unit E210/N98, 20 to $30 \mathrm{~cm}$ depth. Coll Aug 1978. Site previ- 
ously studied by Warren, True, and Endley in 1960 s. This dating permits temporal assessment of occupation studied by them.

\section{LJ-4616. SDM-W-1667}

$6490 \pm 110$

Shells from Site SDM-W-1667, La Jolla site between $\mathrm{W}-1587$ and $-1588\left(33^{\circ} 12^{\prime} 46.4^{\prime \prime} \mathrm{N}, 117^{\circ} 58^{\prime} 24.3^{\prime \prime} \mathrm{W}\right)$. From Unit E101/N71, 30 to 40cm depth. Coll Aug 1978.

\section{LJ-4615. SDM-W-1588}

$7720 \pm 100$

Shells (Chione) from Site SDM-W-1588, La Jolla site on hight knoll between El Camino Real and McGonigle Canyon, on S side of San Dieguito $\mathrm{R}$ at Zanja Marker $\left(33^{\circ} 12^{\prime} 32.7^{\prime \prime} \mathrm{N}, 17^{\circ} 58^{\prime} 26^{\prime \prime} \mathrm{W}\right)$. From Unit E106/N205, 70 to $80 \mathrm{~cm}$ depth. Coll Sept 1978.

\section{LJ-4607. SDM-W-1558}

$$
8290 \pm 100
$$

Shells (Chione, Pecten) from Site SDM-W-1588 (see LJ-4615, above) From Unit E111/N210, 80 to $90 \mathrm{~cm}$ depth. Coll Aug 1978.

\section{LJ-5270. Merriam Mts}

$$
330 \pm 60
$$

$\delta^{13} C=-25.2 \%$

Charcoal flecks from Site SDM-W-1934 (SDi-5951), immediately N of Deer Springs Rd, ca $1200 \mathrm{~m}$ E of its junction with US Hwy 395, in Merriam Mts, E of Vista and NW of Escondido, San Diego Co $\left(33^{\circ} 12^{\prime} \mathrm{N}, 117^{\circ}\right.$ $08^{\prime} \mathrm{W}$ ), from Unit B, 20 to $30 \mathrm{~cm}$ depth. Site attributed to Luiseño inhabitants of Late Prehistoric period. Animal bone fragments and Tizon Brown Ware potsherds found in upper $20 \mathrm{~cm}$ of unit. Coll June 1979; subm by C R Lorenz, Advance Planning and Research Assocs, San Diego. Calibration: AD 1520,1610 (1440 to 1660).

\section{LJ-4880. Fire Mt Ridge}

$1470 \pm 70$

Six shells (Chione) from Site SDM-W-2115, on S slope $\mathrm{C}=+1.4 \%$ Ridge System at alt 67 to $79 \mathrm{~m}$ in Oceanside, San Diego Co $\left(33^{\circ} 11^{\prime} 30^{\prime \prime} \mathrm{N}\right.$ $\left.117^{\circ} 19^{\prime} 58^{\prime \prime} \mathrm{W}\right)$. From Unit E93/N20 of shell midden site with small amount of lithics, dimensions $90 \mathrm{~m} \mathrm{~N}-\mathrm{S}$ by $75 \mathrm{~m} \mathrm{E-W,} 40$ to $50 \mathrm{~cm}$ depth. Coll June 1979 and subm by Carol Walker, Regional Environmental Consultants. Dated to place site in regional chronology.

\section{Grapevine Canyon series}

Two charcoal samples from Huffman site, SDi-1009, in Grapevine Canyon, S of Ranchita, San Diego Co $\left(33^{\circ} 11^{\prime} \mathrm{N}, 116^{\circ} 31^{\prime} \mathrm{W}\right)$. Samples are occupational debris from Test Unit 4 of disturbed campsite with milling and cupule features, suggesting some religious significance. Coll Apr 1979 and subm by $\mathrm{H}$ K Polan, Archaeol Consulting and Technol, Inc, El Cajon.

\section{LJ-4753. Grapevine Canyon, $40-50 \mathrm{~cm}$} $\mathbf{5 8 0} \pm \mathbf{9 0}$

Charcoal from 40 to $50 \mathrm{~cm}$ below surface. Calibration: 1390,1350 1390 (1260 to 1470$)$. 
LJ-4754. Grapevine Canyon, 50-60cm

Charcoal from 50 to $60 \mathrm{~cm}$ below surface. Calibration: AD 1240 (1040 to 1290$)$.

\section{Shadow Ridge series}

Four charcoal samples from Shadow Ridge site, between Vista and

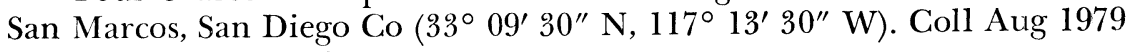
and subm by $\mathrm{H}$ K Polan.

LJ-5112. Shadow Ridge \# 1

$$
600 \pm 60
$$

Charcoal from Test Unit W78 $/ \mathrm{S} 10,30$ to $40 \mathrm{~cm}$ level. Calibration: AD 1320, 1360, 1390 (1280 to 1430).

LJ-5113. Shadow Ridge \#2

$$
\delta^{13} C=-25.5 \%
$$

Charcoal from Test Unit W78 $/ \mathrm{S} 10,40$ to $50 \mathrm{~cm}$ level. Calibration: AD 1420 (1300 to 1470$)$.

LJ-5114. Shadow Ridge \#3

$$
\mathbf{4 0 0} \pm \mathbf{5 0}
$$

Charcoal from Test Unit W107/S46, 30 to $40 \mathrm{~cm}$ level. Calibration: AD 1460 (1420 to 1640$)$.

LJ-5115. Shadow Ridge \#4.

$\mathbf{5 3 0} \pm \mathbf{5 0}$

Charcoal from Test Unit W107/S46, 40 to $50 \mathrm{~cm}$ level. Calibration: AD 1420 (1300 to 1440$)$.

\section{LJ-5427. Carlsbad}

$1600 \pm 70$

Fragmented shell from Site SDM-W-133, above Agua Hedionda Lagoon at end of Skyline Rd, Carlsbad, San Diego Co $\left(33^{\circ} 09^{\prime} 11^{\prime \prime} \mathrm{N}, 117^{\circ}\right.$ $\left.19^{\prime} 04^{\prime \prime} \mathrm{W}\right)$. From Unit E1025/N845, 10 to $20 \mathrm{~cm}$ below ground surface. Coll Feb 1981 and subm by S M Hector, Regional Environmental Consultants. Comment $(\mathrm{SMH})$ : pottery fragments were found at site, and age helps date introduction of ceramics into Luiseño Indian territory from $S$. Possible multiple occupations of site.

\section{La Costa series}

Four shell samples from Site SDM-W-110, shell midden immediately $\mathrm{E}$ of El Camino Real between Palomar Airport Rd and La Costa Ave/ Alga Rd, near La Costa, San Diego Co (33 $\left.06^{\prime} 03^{\prime \prime} \mathrm{N}, 117^{\circ} 16^{\prime} 00^{\prime \prime} \mathrm{W}\right)$. Site may be multi-component, representing Early Milling and Late Prehistoric occupations.

LJ-5299. SDM-W-110

$6270 \pm 70$

Shell from Unit E350/N400, 50 to $60 \mathrm{~cm}$ depth. Coll July 1980 and subm by Carol Walker. 
LJ-5483. SDM-W-110

$6000 \pm 70$ subm by $\mathrm{S} M$ Hector and Carol Walker.

LJ-5484. SDM-W-110

$6670 \pm 50$

Shell from Unit E318/N439, 40 to $50 \mathrm{~cm}$ depth. Coll Jan 1981 and subm by $\mathrm{S} M$ Hector and Carol Walker.

LJ-5485. SDM-W-110

$6650 \pm 40$

$\delta^{13} C=+1.8 \%$

Shell from Unit E312/N458, 30 to 40cm depth. Coll Jan 1981 and subm by $\mathrm{S} M$ Hector and Carol Walker.

\section{El Camino Real/Encinitas Blvd series}

Three charcoal samples from near intersection of El Camino Real and Encinitas Blvd, E of city of Encinitas, San Diego Co. Coll Aug 1978 and subm by M J Hatley, Regional Environmental Consultants.

\section{LJ-4569. SDM-W-1805, 10-20cm}

$1410 \pm 70$

Charcoal from Site SDM-W-1805, ca $760 \mathrm{~m}$ NW of intersection of Camino Real and Encinitas Blvd in rd cut that runs E-W along boundary of Secs 11 and 14, San Diego Co (ca $33^{\circ} 03^{\prime} 02.2^{\prime \prime}$ N, $117^{\circ} 15^{\prime}$ 51.9" W). From Unit 1, 10 to $20 \mathrm{~cm}$ depth. This sample and LJ-4570, below, dated to determine duration of site occupation. Calibration: AD 640 (530 to 720, 750 to 770$)$.

\section{LJ-4570. SDM-W-1805, 50-60cm}

$1230 \pm 60$

Charcoal from Site SDM-W-1805 (see LJ-4569, above). From Unit 1, 50 to $60 \mathrm{~cm}$ depth, from ca $170 \mathrm{~cm}$ away from LJ-4569, above. Comment: age slightly less than that for shallower sample from site. Calibration: AD 780 (660 to 980$)$.

\section{LJ-4567. SDM-W-638}

$$
\mathbf{9 0 0} \pm \mathbf{5 0}
$$

Charcoal from Site SDM-W-638, atop low knoll ca 520m WNW of intersection of El Camino Real and Encinitas Blvd, San Diego Co (ca $33^{\circ}$ $\left.02^{\prime} 49^{\prime \prime} \mathrm{N}, 117^{\circ} 15^{\prime} 49.9^{\prime \prime} \mathrm{W}\right)$. Sample B from Feature II. Charcoal assoc with exposed roasting pit in which diagnostic artifacts were absent. Sample appeared to contain significant amount of lighter material, some of which was removed during lab pretreatment. Calibration: AD 1070, 1130, 1160 (1000 to 1260$)$.

\section{Fairbanks Ranch series}

Ten shell samples from Fairbanks Ranch, Lower San Dieguito Valley, San Diego Co (ca $33^{\circ} 00^{\prime} \mathrm{N}, 117^{\circ} 11^{\prime} \mathrm{W}$ ). Site is highly disturbed, relatively large Early Milling site in lemon and orange orchards. Mean depth of deposits is 40 to $50 \mathrm{~cm}$, with shell relatively scarce and predominantly 
eroded, fragmented Chione. Coll July 1979 and subm by R H Norwood. Dated to improve temporal assessment and to refine obsidian hydration rate for area.

\section{LJ-5160. SDM-W-1356; 21-2; 180}

$$
6200 \pm 70
$$

Whole and fragmented shells (Chione) with eroded surfaces, from 10 to $20 \mathrm{~cm}$ depth of Site W-1356 $\left(33^{\circ} 00^{\prime} 32^{\prime \prime} \mathrm{N}, 117^{\circ} 10^{\prime} 44^{\prime \prime} \mathrm{W}\right)$. Site is relatively small, shallow $(\mathrm{ca} 30 \mathrm{~cm})$ satellite camp of Early Milling occupation, possibly contemporaneous with Site SDM-W-593, below. At SDM-W-1356, shell is scarce and entirely Chione.

LJ-5161. SDi-150C; 4-1,2,3; 475,479,481

$$
\begin{array}{r}
6770 \pm 90 \\
\delta^{13} C=+1.4 \%
\end{array}
$$

Very eroded, fragmented shells (Chione) from 0 to $30 \mathrm{~cm}$ depth at site SDi-150C $\left(33^{\circ} 00^{\prime} 16^{\prime \prime} \mathrm{N}, 117^{\circ} 10^{\prime} 56^{\prime \prime} \mathrm{W}\right)$. Site is a lightly disturbed, relatively large Early Milling deposit, ca $40 \mathrm{~cm}$ in depth. Comment (RHN): specimens provide only opportunity to date substantial Early Milling occupation in which very little shell is present, representing either temporal or functional difference.

\section{LJ-5028. SDM-W-593A; 32-4; 1968}

$$
6460 \pm 80
$$$$
\delta^{13} C=+1.2 \%
$$

Eroded and fragmented shells (Chione, some Pecten) from 30 to $40 \mathrm{~cm}$ depth in Site W-593A $\left(33^{\circ} 00^{\prime} 14^{\prime \prime} \mathrm{N}, 117^{\circ} 11^{\prime} 22^{\prime \prime} \mathrm{W}\right)$. Site has deposit ca $40 \mathrm{~cm}$ in depth and is in lemon grove.

\section{LJ-5030. SDM-W-593A; 3-4; 1774}

Eroded shell fragments (Chione) from 30 to $40 \mathrm{~cm}$ depth in Site W-593A (see LJ-5028, above). Site apparently represents base camp of relatively large size, surrounded by smaller, non-datable sites. Comment (RHN): obsidian was recovered from 10 to $20 \mathrm{~cm}$ level of this unit; hydration measurement is $5.2 \mu$, with possible age of $5426 \mathrm{yr}$ BP.

\section{LJ-5029. SDM-W-593B; 42-4; 2131}

$6820 \pm 100$

$\delta^{13} \mathrm{C}=+1.5 \%$

Eroded shell (Chione) from 30 to $40 \mathrm{~cm}$ depth in Site W-593B $\left(33^{\circ} 00^{\prime}\right.$ $\left.13^{\prime \prime} \mathrm{N}, 117^{\circ} 11^{\prime} 23^{\prime \prime} \mathrm{W}\right)$. Comment (RHN): specimens were obtained from shell lens and were directly assoc with obsidian giving hydration measurements of $5.9 \mu, 8.2 \mu$, and $5.3 \mu$, corresponding to possible absolute age range of 5045 to $7086 \mathrm{yr}$ вP.

\section{LJ-5155. SDM-W-593B; 16-3; 14}

$6200 \pm 70$

Relatively large shell fragments (Chione) from lens at 20 to $30 \mathrm{~cm}$ depth at Site W-593B $\left(33^{\circ} 00^{\prime} 13^{\prime \prime} \mathrm{N}, 117^{\circ} 11^{\prime} 23^{\prime \prime} \mathrm{W}\right)$.

\section{LJ-5156. SDM-W -593C; $26-3 ; 14$}

$$
6400 \pm 70
$$

$$
\delta^{13} \mathrm{C}=+1.1 \% \mathrm{c}
$$

Relatively small, eroded shell specimens (Chione) from 20 to $30 \mathrm{~cm}$ depth at Site W-593C $\left(33^{\circ} 00^{\prime} 11^{\prime \prime} \mathrm{N}, 117^{\circ} 11^{\prime} 24^{\prime \prime} \mathrm{W}\right)$. 
LJ-5157. SDM-W-593C; 58-3; 2237

$$
\begin{array}{r}
\mathbf{6 5 2 0} \pm \mathbf{7 0} \\
\delta^{13} C=+1.4 \% \text { o }
\end{array}
$$

Eroded shells (Chione, some Pecten) from 20 to $30 \mathrm{~cm}$ depth at Site W-593C (see LJ-5156, above).

\section{LJ-5158. SDM-W-596; 26-5; 704}

$7110 \pm 70$ at Site W-596 $\left(32^{\circ} 59^{\prime} 59^{\prime \prime} \mathrm{N}, 117^{\circ} 10^{\prime} 46^{\prime \prime} \mathrm{W}\right)$. Rens at 40 to $50 \mathrm{~cm}$ depth and Chione shells were found at site. Age helps date subsistence change (from Pecten to Chione). Site is anomaly in immediate area and may represent different occupation or function.

\section{LJ-5159. SDM-W-596; 38-7; 875}

$7230 \pm 80$

Fragmen depth at Site W-596 (see LJ-5158, above). Date places lower, relatively undisturbed portion of site in temporal perspective at period when diversity of shell sp was exploited.

\section{San Clemente Island series}

Sixteen samples from San Clemente I., Southern California coastal island were coll and subm by L M Axford and assocs, Mesa Coll, San Diego. Samples measured to date human habitation on island and to contribute to S coastal chronology. Series previously reported in Linick (1979; 1980).

\section{LJ-4172. SCLI/RC-10, charcoal}

$4500 \pm 400$

Charcoal from inside rock shelter at Sitc $\left.118^{\circ} 35^{\prime} 51.35^{\prime \prime} \mathrm{W}\right)$. Very small sample taken at depth 38 to $43 \mathrm{~cm}$ from nominal floor, $116 \mathrm{~cm}$ down from ceiling. Coll Oct 1977 and subm by L M Axford and R M Carlson. Comment: age agrees very well with $4950 \pm 90$ apparent age for shell sample from same provenience dated previously (LJ-4169: R, 1980, v 22, p 1036), especially considering marine reservoir effect on shell age. Shell sample from same site, depth $70 \mathrm{~cm}$ from nominal floor, $140 \mathrm{~cm}$ down from ceiling, gave apparent age of $6300 \pm 90$ (LJ-4168: R, 1980, v 22, p 1036). Calibration: 3340 BC (3885 to 2405).

\section{LJ-5411. SCLI/RC-19, shell}

$3520 \pm 320$

Marine shell from Site SCLI- 36 (T 36$)\left(33^{\circ} 00^{\prime} 08^{\prime \prime} \mathrm{N}, 118^{\circ}=0.0 \%\right.$ W). From center of site, from post hole ca $36 \mathrm{~cm}$ deep. Coll Nov 1975 by L M Axford and Roxie Phillips.

\section{LJ-4220. SCLI/RC-11, shell}

$$
300 \pm 400
$$

Small piece of abalone shell from Site SCLI-1167, at $S$ end of earthen dam in valley $\mathrm{NW}$ of national forest on main island $\mathrm{rd}\left(32^{\circ} 58^{\prime} 01.453^{\prime \prime} \mathrm{N}\right.$, $\left.118^{\circ} 32^{\prime} 27.240^{\prime \prime} \mathrm{W}\right)$. Taken at depth 10 to $23 \mathrm{~cm}$. Coll Dec 1977 and subm by L M Axford and R M Carlson. Comment: age for charcoal sample 
from same provenience dated previously, $430 \pm 70$ (LJ-4219: R, 1980, v 22, p 1036).

$\begin{array}{ll}\text { LJ-5303. SCLI/RC-22, charcoal/seeds/ } & \mathbf{2 5 4 0} \pm \mathbf{2 1 0} \\ \text { ash/soil } & \text { Est } \boldsymbol{\delta}^{13} \mathrm{C}=-25.0 \%\end{array}$

Charcoal, seeds, ash, and soil from Site SCLI-1156 $\left(32^{\circ} 58^{\prime} 00.7^{\prime \prime} \mathrm{N}\right.$, $\left.118^{\circ} 32^{\prime} 29.1^{\prime \prime} \mathrm{W}\right)$. From upper terrace living site, $200 \mathrm{~m} \mathrm{~N}$ of natl forest. Coll May 1979 and subm by L M Axford. Calibration: 800 BC (1095 to 205).

\section{LJ-5037. SCLI/RC-22, shell}

Shell from same provenience as LJ-5303, above. Coll May 1979 and subm by L M Axford.

\section{LJ-4646. SCLI/RC-16, charcoal}

$1840 \pm 60$

Charcoal from Site SCLI-1349 (32 57' 06.121" N, 118 37' 01.121"

W). Sample removed from post hole in center of house depression. Coll Oct 1978 and subm by L M Axford and T Boone. Calibration: AD 150, 210 (10 to 340$)$.

\section{LJ-4673. SCLI/RC-18, shell}

$960 \pm 60$

Five black abalone shells, each ca 3.8 to $8.9 \mathrm{~cm}$ long, from Site SCLI1360 (32 $\left.56^{\prime} 47.87^{\prime \prime} \mathrm{N}, 118^{\circ} 29^{\prime} 49.12^{\prime \prime} \mathrm{W}\right)$. From collapsed rock shelter. Coll Nov 1978 and subm by L M Axford and T Boone.

\section{LJ-4647. SCLI/RC-17, charcoal}

$1770 \pm 60$

Charcoal from Site SCLI-1351 (320 56' 42 93" N, $\left.118^{\circ} 31^{\prime} 04.99^{\prime \prime} \mathrm{W}\right)$ Coll from Pit B, from depth 18 to $23 \mathrm{~cm}$, in house depression. Coll Oct 1978 and subm by L M Axford and T Boone. Calibration: AD 240, 310 (80 to 420 ).

\section{LJ-4672. SCLI/RC-17, shell}

$\mathbf{8 5 0} \pm \mathbf{5 0}$

Shell from same provenience as LJ-4647, above. Coll Oct 1978 and subm by $\mathrm{L} \mathrm{M}$ Axford and $\mathrm{T}$ Boone.

LJ-5643. SCLI/RC-23, charcoal

$500 \pm 70$

Charcoal fragments from Site SCLI-1075 (320 $59135.68^{\prime \prime} \mathrm{N}, 118^{\circ} 3$ $\left.18.11^{\prime \prime} \mathrm{W}\right)$. From middle of house depression, from depth 5 to $10 \mathrm{~cm}$. Coll May 1977 by L M Axford and L D Lindmark; subm by L M Axford. Calibration: AD 1420 (1300 to 1490).

LJ-5640. SCLI/RC-24, shell $1000 \pm 60$

Shells (black abalone, owl limpet, and tecula sea snail) from same provenience as LJ-5643, above. Coll May 1977 by L M Axford and L D Lindmark; subm by L M Axford. Comment: when marine reservoir age is subtracted from apparent age of LJ-5640, ages of LJ-5643 and -5640 agree reasonably well. 
LJ-5641. SCLI/RC-25, charcoal

Charcoal fragments from Site SCII-1074 $\left(32^{\circ} 53^{\prime} 35.43^{\prime \prime} \mathrm{N}, 118^{\circ} 31^{\prime}\right.$ $27.80^{\prime \prime} \mathrm{W}$ ). From fire lens of living area, from depth 10 to $15 \mathrm{~cm}$. Coll May 1977 by L M Axford and L D Lindmark; subm by L M Axford. Calibration: AD $1670,1760,1800$ (1640 to 1690,1720 to 1820,1920 to 1950$)$.

\section{LJ-5639. SCLI/RC-25, shell}

$1340 \pm 60$ provenience as LJ-5641, above). Coll May 1977 by L M Axford and L D Lindmark; subm by L M Axford. Comment: even after subtracting marine reservoir age, shell age is much greater than that of LJ-5641 charcoal.

\section{LJ-5302. SCLI/RC-20, charcoal}

$310 \pm 180$

Charcoal from Site SCLI-1504 (32 $\left.50^{\prime} 36^{\prime \prime} \mathrm{N}, 118^{\circ} 28^{\prime} 32^{\prime \prime} \mathrm{W}\right)$, from $10 \mathrm{~cm}$ depth. Coll Apr 1979 and subm by L M Axford and T Boone. Calibration: AD 1550, 1630 (1290 to 1950).

\section{LJ-5306. SCLI/RC-20, shell}

$$
\begin{array}{r}
\mathbf{2 3 4 0} \pm \mathbf{7 0} \\
\delta^{13} \mathrm{C}=+2.2 \% 0
\end{array}
$$

Green abalone shell from same provenience as LJ-5302, above. Coll Apr 1979 and subm by L M Axford and T Boone. Comment: even after subtracting marine reservoir age, shell age is much greater than that of LJ-5302 charcoal.

LJ-5304. SCLI/RC-21, charcoal

$$
1280 \pm 60
$$$$
\delta^{13} \mathrm{C}=-22.2 \%
$$

Large charcoal sample from wall of cave site, SCLI-1505 (32 $50^{\prime} 32^{\prime \prime}$ $\left.\mathrm{N}, 118^{\circ} 28^{\prime} 10^{\prime \prime} \mathrm{W}\right)$. Coll Apr 1979 and subm by L M Axford and T Boone. Calibration: AD 700, 760 (640 to 890$)$.

\section{Del Mar series}

Three shell samples taken to establish date for coastal shellfish exploitation sites in vicinity of Del Mar, San Diego Co. Subm by S M Hector.

\section{LJ-5665. SDM-W-25A}

$6160 \pm 50$

Shells (Chione, Pecten) from Site SDM-W-25A, adjacent to San Dieguito Lagoon, Del Mar ( $\left.32^{\circ} 57^{\prime} 30^{\prime \prime} \mathrm{N}, 117^{\circ} 14^{\prime} 45^{\prime \prime} \mathrm{W}\right)$, from 0 to $10 \mathrm{~cm}$ depth. Coll May 1982 by S M Hector.

\section{LJ-5668. SDM-W-2302}

$$
6040 \pm 40
$$

Shells (Pecten) from Site SDM-W-2302, adjacent to San Dieguito goon, Del Mar $\left(32^{\circ} 57^{\prime} 15^{\prime \prime} \mathrm{N}, 117^{\circ} 14^{\prime} 30^{\prime \prime} \mathrm{W}\right)$. From 0 to $10 \mathrm{~cm}$ depth. Coll May 1982 by S M Hector.
LJ-5667. SDM-W-1291A
$2450 \pm 30$
Shells (mainly Pecten, some Chione) from Site SDM-W-1291A, N of 
Carroll Canyon, Del Mar $\left(32^{\circ} 56^{\prime} 30^{\prime \prime} \mathrm{N}, 117^{\circ} 14^{\prime} 30^{\prime \prime} \mathrm{W}\right)$, from 70 to $100 \mathrm{~cm}$ depth. Coll Oct 1980 by R H Norwood.

\section{Rancho Peñasquitos series}

Two charcoal samples from Rancho Peñasquitos area, San Diego Co. Coll July 1980 and subm by R H Norwood.

\section{LJ-5266. Rancho Peñasquitos, SDM-W-1339A $\delta^{13} C=-24.1 \%$}

Charcoal removed from bulk soil sample excavated at Site SDM-W1339A, $100 \mathrm{~m} \mathrm{~S}$ of intersection of Rancho Peñasquitos Blvd and Carmel Mt Rd, San Diego Co (32 $56^{\prime} 20^{\prime \prime} \mathrm{N}, 117^{\circ} 07^{\prime} 20^{\prime \prime} \mathrm{W}$ ), from 20 to $40 \mathrm{~cm}$ depth. Site consists of portion of large Late Prehistoric village. Deposit is relatively shallow $(\mathrm{ca} 50 \mathrm{~cm})$ and may also have Early Milling component. Comment (RHN): only absolute date for occupation; it helps evaluate obsidian hydration results. Calibration: AD 1660 (1520 to 1880, 1910 to 1950).

\section{L-5265 Rancho Peñasquitos, SDM-W-1337 $\delta^{13} C=-250 \pm 40$}

Charcoal removed from large bulk soil sample excavated at Site SDMW-1337, in canyon between Rancho Peñasquitos Blvd and Peñasquitos Canyon, San Diego Co $\left(32^{\circ} 56^{\prime} 25^{\prime \prime} \mathrm{N}, 117^{\circ} 07^{\prime} 25^{\prime \prime} \mathrm{W}\right)$, from 20 to $40 \mathrm{~cm}$ depth in deposit up to $100 \mathrm{~cm}$ deep. Site consists of small Late Prehistoric campsite with developed midden of ca $600 \mathrm{~m}^{2}$ area. Ceramics and small desert side-notched points were present. Comment (RHN): only date for occupation. Date permits assessment of contemporaneous occupation of this site and SDM-W-1339 (see LJ-5266, above) to N. Calibration: AD 1640 (1520 to 1670,1740 to 1800 ).

\section{LJ-5291. Sorrento Valley}

$\mathbf{5 7 0} \pm \mathbf{1 3 0}$

Carbonate from burned human rib bones from Bailey property, Site SDM-W-654, Roselle St, Sorrento Valley, San Diego Co $\left(32^{\circ} 54^{\prime} \mathrm{N}, 117^{\circ}\right.$ 13' W). Coll May 1980 and subm by R A Tyson, San Diego Mus of Man, San Diego. Comment (RAT): rib bones are from secondary burial which was being washed out of side of creek bed. There were parts of two individuals in burial_-adult and adolescent. Both skeletons show signs of breaking and burning. Some bones were split and broken before they were burned. Soil contains shell and flakes, but no pottery. Soil is dark and contains small pieces of charcoal. Midden may be of La Jollan age, but human remains could be from later period.

\section{LJ-1568. Soledad Canyon}

$720 \pm 60$

$\delta^{13} C=-22.5 \%$

Charcoal from Site SDi-4609, ca $180 \mathrm{~m} \mathrm{~N}$ of terminus of Roselle St in Soledlad Canyon, San Diego Co (ca 32 $53^{\prime} 35.3^{\prime \prime} \mathrm{N}, 117^{\circ} 12^{\prime} 56.9^{\prime \prime} \mathrm{W}$ ). From NW corner of Unit $1,60 \mathrm{~cm}$ depth. Unit was in well-developed drainage $S$ of AT\&SF RR track, ca $50 \mathrm{~cm}$ from fill layer that was on top of natural ground surface; some of site was probably covered by this fill. Sample came from interface between ceramic and pre-ceramic-bearing de- 
posits. Coll Aug 1978 and subm by M J Hatley. Calibration: AD 1280 (1190 to 1330,1350 to 1390 ).

\section{Campus Point series}

Four shell samples from Site SDM-W-1668, designated Campus Point site, at junction of Interstate Hwy 5 and Genesee Ave, San Diego (32 $53^{\prime}$ $35^{\prime \prime} \mathrm{N}, 117^{\circ} 13^{\prime} 18.37^{\prime \prime} \mathrm{W}$ ). Site is on gently sloping mesa, $11,000 \mathrm{~m}^{2}$ in area, at alt $107 \mathrm{~m}$. Coll Feb 1979 and subm by Darla Ferguson, Regional Environmental Consultants. Dated to determine whether there was temporal difference between two main areas of shell concentrations found at site. Comment: as seen from results below, answer remains ambiguous.

\section{LJ-4875. Campus Point, top of knoll}

$$
6570 \pm 110
$$

One shell (Chione) from 10 to $20 \mathrm{~cm}$ depth in smaller, shallower shell concentration on top of knoll.

\section{LJ-4877. Campus Point, top of knoll}

$5390 \pm 90$ shell concentration on top of knoll.

\section{LJ-4876. Campus Point, SE of knoll}

$\delta^{13} \mathrm{C}=+1.0 \%$ concentration SE of knoll.

\section{LJ-4874. Campus Point, SE of knoll}

Two shells (Chione) from 70 to $80 \mathrm{~cm}$ depth in larger, deeper shell concentration SE of knoll.

\section{Santee Greens series}

Three charcoal samples from Santee Greens, Site SDi-5669, 60,000+ ha, dating to Late Archaic cultural horizon in Santee, San Diego Co $\left(32^{\circ}\right.$ $\left.51^{\prime} 15^{\prime \prime} \mathrm{N}, 116^{\circ} 58^{\prime} 08^{\prime \prime} \mathrm{W}\right)$. Charcoal was assoc with potsherds. Coll May 1979 and subm by H K Polan. Dated to redefine advent of ceramic manufacture in area.

LJ-4853. Santee Greens, $70-80 \mathrm{~cm}$

$90 \pm 70$

Charcoal from Test Unit E188.5/N26.4, 70 to $80 \mathrm{~cm}$ depth. Calibration: AD $1720,1890,1910$ (1650 to 1950$)$.

\section{LJ-4851. Santee Greens, 100-110cm}

$\mathbf{8 6 0} \pm \mathbf{5 0}$

Charcoal from Test Unit E188.5/N30.1, 100 to $110 \mathrm{~cm}$ depth. Caliba tion: AD 1190 (1020 to 1270).

\section{LJ-4852. Santee Greens, $110-120 \mathrm{~cm}$} $110 \pm 70$

Charcoal from Test Unit E188.5/N26.4, 110 to $120 \mathrm{~cm}$ depth. Calibration: AD $1700,1840,1910$ (1640 to 1950$)$. 


\section{LJ-4565/LJ-4566. Encanto}

$3600 \pm 110$

Charcoal flecks from Site SDM-W-1504, "La Jolla" site in S Chollas drainage, on bench of land SW of intersection of 60th St and Federal Ave in Encanto area of San Diego $\left(32^{\circ} 43^{\prime} 26.8^{\prime \prime} \mathrm{N}, 117^{\circ} 03^{\prime} 43.44^{\prime \prime} \mathrm{W}\right)$. Part of sample came from Unit E29/N45, 30 to $40 \mathrm{~cm}$ depth, assoc with firecracked rock and burned artifacts; other part came from similar context in another unit. Site has been destroyed by grading and cannot be retested. Coll Dec 1977 and subm by R H Norwood. Comment (RHN): lack of shell and artifact morphology suggested age of ca 2500 to $3600 \mathrm{BP}$, possible period of re-adaptation from coastal to inland resources just prior to Yuman Indian intrusion. Calibration: 2100 to 1960 BC (2300 to 1710).

\section{Mother Grundy Truck Trail series}

Two charcoal samples from Site SDM-W-370 B/C, small encampment midden adjacent to Mother Grundy Truck Trail just $\mathrm{N}$ of Mother Grundy Peak, San Diego Co (32 $\left.39^{\prime} 30^{\prime \prime} \mathrm{N}, 116^{\circ} 45^{\prime} 30^{\prime \prime} \mathrm{W}\right)$. Coll July 1979 by William Baker; subm by D M Van Horn, Archaeol Associates, Ltd, Costa Mesa.

\section{LJ-5128. Mother Grundy, $20-30 \mathrm{~cm}$}

$$
\begin{array}{r}
460 \pm 40 \\
\delta^{13} C=-25.4 \%
\end{array}
$$

Loose charcoal from Unit $318^{\circ} 7 \mathrm{~m}, 20$ to $30 \mathrm{~cm}$ level of unstratified midden. Sample is from deepest pottery-bearing level of unit. Non-ceramic-bearing levels were found below this level. While sample was found at relatively shallow level, there was no indication of disturbance, such as Historic artifacts or plowing, at this level. Calibration: AD 1440 (1410 to 1490).

\section{LJ-5129. Mother Grundy, 90-100em}

$670 \pm 80$

Charcoal from Unit $318^{\circ} 7 \mathrm{~m}, 90$ to $100 \mathrm{~cm}$ level of unstratified midden. Sample is free from deep part of lower, aceramic phase of midden. Comment (DMVH): it was suspected that there might have been substantial time gap between deposits of ceramic and aceramic phases. Calibration: AD 1290 (1210 to 1420$)$.

\section{LJ-5094. Jacumba}

$380 \pm 60$

Charcoal pieces dispersed from campfires at bottom of midden assoc with rock shelter at Site SDi-4326 near Jacumba, SE corner of San Diego Co $\left(32^{\circ} 39^{\prime} 16^{\prime \prime} \mathrm{N}, 116^{\circ} 10^{\prime} 00^{\prime \prime} \mathrm{W}\right)$. Site was Kumeyaay Indian village, Ha'a'weer. Charcoal recovered from 20 to $30 \mathrm{~cm}$ depth level of test unit, $2 \mathrm{~m}$ by $2 \mathrm{~m}$ and 30 to $39 \mathrm{~cm}$ deep. 20 to $30 \mathrm{~cm}$ depth level was almost on bedrock, with $\max 39 \mathrm{~cm}$ depth due to pocket of midden in rock. Coll Sept 1979 and subm by R V May, San Diego Co Archaeol Soc. Comment (RVM): area was not dated previously and was possibly earliest site for introduction of pottery and agric in area. Site was 1 of ca 6 major occupation sites in valley; rock shelter with "chain diamond" petroglyph was ca 
$2 \mathrm{~m} \mathrm{E}$ of test unit. Before this analysis, possible age of $>2000 \mathrm{yr}$ BP was hypothesized due to discovery of oxidized flakes; however, assoc of manos, small triangular arrow points, and non-oxidized flakes suggested more modern age. ${ }^{14} \mathrm{C}$ date suggests that populations assoc with exploitation of Lake Cahuilla (AD 950 to 1500) moved W up into mts after dessication of region (AD 1450 to 1500 ). Impacts upon $\mathrm{mt}$ cultures are presently being studied. Calibration: AD 1470 (1420 to 1640).

\section{Santa Catalina Island series}

Two charcoal samples from UCLA Site No. SCaI-137, Bullrush Canyon Site No. 1, Santa Catalina I., Los Angeles Co $\left(32^{\circ} 21^{\prime} \mathrm{N}, 118^{\circ} 27^{\prime} \mathrm{W}\right)$. Coll $3.62 \mathrm{~km}$ from mouth of canyon, at $229 \mathrm{~m}$ alt, NW corner of this Southern California coastal island. Coll Apr 1979 by M Cottrell; subm by Adella Schroth. Dated for comparison with those from Little Harbor site.

\section{LJ-4755. Santa Catalina I., $25 \mathrm{~cm}$ \\ $\delta^{13} C=25.3 \%$}

$270 \pm 100$ $1670,1740$ to 1800$)$.

\section{LJ-4756. Santa Catalina I., Level 1}

Charcoal from Unit 1-A, Level 1. Calibration: AD 1490 (1440 to 1640).

\section{LJ-4648. Kumeyaay site, SDSU No. F:5:1}

$\mathbf{3 1 0} \pm \mathbf{5 0}$

$\delta^{13} C=-25.4 \%$

Charcoal from San Diego State Univ Site No. F:5:1, San Diego Co (ca $32^{\circ} \mathrm{N}, 117^{\circ} \mathrm{W}$ ). Site is Prehistoric Kumeyaay Indian site. Coll Dec 1978 and subm by C A McGowan, Southwestern Coll, Chula Vista. Other ${ }^{14} \mathrm{C}$ ages for charcoal from same site are $340 \pm 60$ and $320 \pm 50$ (L J-3456 and -3800 , respectively: $\mathrm{R}, 1979$, v 21, p 194). Calibration: AD 1550, 1630 (1450 to 1660$)$.

\section{LJ-5134. Kumeyaay cremation site}

$$
\delta^{1.3} C=-24.1 \% \text { o }
$$

Charcoal from Late Prehistoric Kumeyaay portion of 2- or 3-component site in San Diego Co (ca $\left.32^{\circ} \mathrm{N}, 117^{\circ} \mathrm{W}\right)$. Charcoal found at 30 to $38 \mathrm{~cm}$ depth below surface assoc with human cremation. Coll Dec 1979 and subm by C A McGowan. Calibration: AD 1640 (1450 to 1690, 1730 to 1810 , 1940 to 1950$)$.

\section{Mexico}

\section{LJ-5301. Temoris}

$$
\begin{array}{r}
\mathbf{8 6 0} \pm \mathbf{4 0} \\
\delta^{1.3} \mathrm{C}=-26.3 \% \text {. }
\end{array}
$$

Twisted cordage (possibly Apocynum sp) of string skirt of mummy found in cave at alt $2000 \mathrm{~m}$ in Sierra Madre Occidental Mts, near Temoris, SW part of State of Chihuahua, near border with State of Sonora $\left(27^{\circ} 40^{\prime}\right.$ $\left.\mathrm{N}, 108^{\circ} 35^{\prime} \mathrm{W}\right)$. Remains found $60 \mathrm{~cm}$ below surface of dry cave, wrapped in cane mat, with food offerings of corn, berries, and dried meat. Mummy was that of young female, well-preserved by natural dehydration. X-rays show fetus of 7 to 8 months gestational age in pelvic area. Coll winter 
1966 by William Glad and Gilbert Ballow, San Diego, from whom it was confiscated by sheriff and brought to Mus of Man. Arrangements made with Inst Nacional Antropología e Historia, Mexico City for return of mummy following study. Subm by R A Tyson. Calibration: AD 1190 (1040 to 1260$)$.

\section{Belize series}

\section{Belize}

Eight charcoal samples from Mayan site in Cuello (ca $17^{\circ} \mathrm{N}, 88^{\circ} \mathrm{W}$ ). Coll and subm by Norman Hammond, Archaeol Research Prog, Douglass Coll, Rutgers Univ, New Brunswick, New Jersey. Comment (NH): dates of LJ-4917 to -4920 and -4922 to -4923 are substantially younger than expected on basis of previous Cambridge and UCLA work. "Compression" of dates from long stratigraphic sequence to very short span of ${ }^{14} \mathrm{C}$ time has been duplicated by Cambridge Univ lab (Q), in that samples with expected ${ }^{14} \mathrm{C}$ ages younger than $2400 \mathrm{BP}$ have yielded dates in agreement with those expectations, while samples expected to be older than 2400 BP have yielded ages within very narrow range. No explanation is available for this discrepancy, although only restricted area of excavation is involved.

\section{LJ-4921. Belize \#6}

$2160 \pm 60$

Charcoal from Late Formative level in Unit 45/50. Dates expansion of $\mathrm{NE}$ quad of site. Comment $(\mathrm{NH}):{ }^{14} \mathrm{C}$ age acceptable and within expected range, 2250 to $2950 \mathrm{BP}$. Calibration: 380 to $180 \mathrm{BC}$ (395 to 20).

\section{LJ-4916. Belize \# 1}

$2180 \pm 70$

Charcoal from Late Formative, first phase of pyramid construction, from Unit 25/50. Date important to establish beginning of ceremonial construction and to link pyramid sequence with deep sounding in Unit $35 / 30,10 \mathrm{~m}$ to $\mathrm{NE}$. Comment $(\mathrm{NH}):{ }^{14} \mathrm{C}$ age later than expected range, 2950 to $3050 \mathrm{BP}$, but this may simply indicate initial overestimation of age and later beginning of pyramid construction. Calibration: 385 to $180 \mathrm{BC}$ (400 to 30$)$.

\section{LJ-4920. Belize \#5}

$$
\begin{array}{r}
\mathbf{2 4 2 0} \pm \mathbf{7 0} \\
\delta^{13} C=-2.6 .9 \% \text { o }
\end{array}
$$

Charcoal from early Middle Formative (Phase IV) burial (Feature 32), from Unit 35/30. Provides terminus ante quem for building in which burial was intruded. Comment $(\mathrm{NH}):{ }^{14} \mathrm{C}$ age younger than expected range, 2850 to $3050 \mathrm{BP}$, but still within range of acceptability. Calibration: 765 to 595 вс (775 to 395$)$.

\section{LJ-4919. Belize \#4}

$$
\begin{array}{r}
2490 \pm 70 \\
\delta^{1.3} C=-26.8 \%
\end{array}
$$

Charcoal from middle of Building Phase III of Early Formative, from Unit 35/30. Dated to define Phase III/IIIA boundary. Comment (NH): original expected ${ }^{14} \mathrm{C}$ age, 3250 to $3650 \mathrm{BP}$, has been reduced since sample 
was subm, but result is still several centuries younger than expectation. Calibration: 780 BC (795 to 415$)$.

\section{LJ-4922. Belize \#7}

Charcoal from early Phase III Early Formative patio, from Unit 35/30. Dated to define Phase III/IIIA boundary. Comment (NH): same as for LJ-4919, above, except original expectation was 3650 BP for LJ-4922. Calibration: 800 BC (805 to 420$)$.

\section{LJ-4923. Belize \#8}

$2510 \pm 60$

$\delta^{13} C=-26.4 \%$ o

Charcoal from early Phase III of Early Formative, from Unit 35/30. Dated to define Phase III/IIIA boundary. Comment (NH): expected age, $3650 \mathrm{BP} .{ }^{14} \mathrm{C}$ age is much younger than expected and is inseparable from late Phase III ages, noted above, which does not accord with stratigraphy or ceramic sequence. Calibration: 790 BC (800 to 420$)$.

\section{LJ-4917. Belize \#2}

$$
\begin{array}{r}
2420 \pm 60 \\
\delta^{1 s} C=-26.0 \% \text { o }
\end{array}
$$

Charcoal from fireplace (Feature 64) of Building Phase II of Early Formative, from Unit 35/30. This was scaled sample from short-use context early in sequence. Comment $(\mathrm{NH})$ : expected age, 3550 to $3800 \mathrm{BP}$. Date is much younger than expected and is inseparable from both late and early Phase III ages, noted above, which does not accord with stratigraphy or ceramic sequence. Calibration: 765 to 595 BC (775 to 395).

\section{LJ-4918. Belize \#3}

$$
\mathbf{2 4 7 0} \pm \mathbf{7 0}
$$$$
\delta^{1 s} C=-27.6 \% \text { o }
$$

Charcoal from Early Formative early occupation level with first effigy whistles, from Unit 35/35. Important for linking Units 35/35 and 35/30 and to date earliest musical instrument in Mayan area. Comment (NH): younger than expected ${ }^{14} \mathrm{C}$ age, $3750 \mathrm{BP}$, by several centuries, even at lower limit of calibration. Calibration: $780 \mathrm{BC}(790$ to 410$)$.

\section{Peruvian Amazonia series}

$$
\text { Peru }
$$

Eight charcoal samples from Peruvian Amazon forest region. All samples are from middle Yubineto $\mathrm{R}$ basin in Secoya Indian territory; Yubineto $\mathrm{R}$ is right affluent of Putamayo $\mathrm{R}$, river that forms Colombia-Peru border, on Peruvian side (ca $1^{\circ} \mathrm{S}, 74^{\circ}$ to $75^{\circ} \mathrm{W}$ ). Coll Dec 1977 to Sept 1978 by S F Paitan; subm by Jürg Gasché, Paris, France. Dated to provide insight into problems of age of agric in Amazon region, pattern of agric exploitation of forest by Indian farmers, and speed of forest regeneration under native exploitation conditions. This study was part of proj, "Shifting cultivation and evolution of the forest milieu of Northwestern Amazonia. Ecology of native cultivation systems in Peruvian Amazonia," funded by Swiss Natl Foundation for Sci Research and French Natl Center for Sci Research. 
LJ-4787. Bellavista, Loma 5, 1Bp-B

$$
1890 \pm 40
$$

Charcoal from Bellavista site, Loma 5,5 to $50 \mathrm{~cm}$ depth. Sample from same site, 100 to $150 \mathrm{~cm}$ depth, contained no charcoal. Calibration: AD 100 (10 to 230$)$.

LJ-4868. Bellavista, Loma 4, 2Bp-B $1920 \pm 60$ Charcoal from Bellavista site, Loma 4,5 to $50 \mathrm{~cm}$ depth. Sample from same site, 80 to $120 \mathrm{~cm}$ depth, contained no charcoal. Calibration: AD 30 , 70 (40 BC to AD 230).

\section{LJ-4870. Bellavista, Loma 3, 3Bp-B}

$$
1180 \pm 60
$$
AD 830 (680 to 980$)$.

\section{LJ-4871. Escuela Vieja, 4Bp-EV}

$$
1250 \pm 60
$$

Charcoal from Escuela Vieja site, 10 to $40 \mathrm{~cm}$ depth. Calibration: $\mathrm{AD}$ 690, 720, 750, 780 (650 to 900,900 to 940 ).

\section{LJ-4872. Escuela Vieja, Purma-8A, 5P-EV, $\quad \Delta=+143 \pm 8 \%$ $0 \mathrm{~cm}$ \\ $\delta^{13} \mathrm{C}=-30.7 \%$}

Charcoal from Escuela Vieja site, Purma-8A, $0 \mathrm{~cm}$ depth. Calibration: more recent than AD 1957.

\section{LJ-4873. Escuela Vieja, Purma-8A, 5P-EV, $\quad 2140 \pm 50$ $20.40 \mathrm{~cm}$ \\ $\delta^{13} C=-29.1 \%$}

Charcoal from Escuela Vieja site, Purma-8A, 20 to $40 \mathrm{~cm}$ depth. Calibration: 375 to 180 вС (390 to 50$)$.

\section{LJ-4653. Mamepo, 15Bp, 20-50cm}

Charcoal from Mamo (840 to 410$)$.

\section{LJ-4652. Mamepo, $15 B \mathrm{p}, 50-100 \mathrm{~cm}$}

$2430 \pm 40$

Charcoal from Mamepo site, 50 to $100 \mathrm{~cm}$ depth. Calibration: 770 to $590 \mathrm{BC}(780$ to 400$)$.

\section{Traful Cave series}

\section{Argentina}

Four charcoal samples from Traful Cave $1,2 \mathrm{~km} \mathrm{~W}$ of Confluencia, Prov Neuquen $\left(40^{\circ} 43^{\prime} \mathrm{S}, 71^{\circ} 07^{\prime} \mathrm{W}\right)$. Site is small cave, containing $2 \mathrm{~m}$ deposits including rodent bones and Indian artifacts. Cave was occupied alternately by owls and Indians. Long sequence of small mammal bones of $18 \mathrm{sp}$ provided unique opportunity to trace long-term faunal history of region as well as climatic history, since many of these sp have narrow climatic requirements. Dated Indian material from region is very scarce. Coll by Lic M J Silveira and assocs, Inst Ciencias Antropologicas, Buenos 
Aires; subm by O P Pearson, Mus Vertebrate Zool, Univ California, Berkeley.

LJ-5130. Traful Cave, Layer 3a

$$
2330 \pm 40
$$
July 1979. Calibration: 490 to 390 BC $(490$ to 160$)$

\section{LJ-5131. Traful Cave, Layer 6}

$$
2720 \pm 40
$$

$\delta^{13} \mathrm{C}=-26.4 \%$

Charcoal from Layer 6 (middle), coordinates $\mathrm{Hu}, 123 \mathrm{~cm}$ depth. Coll Oct 1979. Calibration: 1020 to 860 BC (1045 to 785$)$.

\section{LJ-5132. Traful Cave, Layer 9}

$$
6240 \pm 60
$$

Charcoal from Layer 9, coordinates $\mathrm{Ik}, 45$ to $5 \mathrm{lcm}$ depth. Coll Aug 1979. Calibration: 5300 to 5150 BC (5365 to 4975 ).

\section{LJ-5133. Traful Cave, Layer 10}

$$
\begin{array}{r}
\mathbf{7 8 5 0} \pm \mathbf{7 0} \\
\delta^{13} C=-25.1 \%
\end{array}
$$

Charcoal from Layer 10, coordinates Hp-Ho, 174 to $182 \mathrm{~cm}$ depth. Coll Sept 1979. Calibration: 6830 to 6600 BC (7030 to 6450).

\section{Egyptian mummy series}

$$
\text { Egypt }
$$

Tissue and wrapping bandages from Manchester Mummy 1770, obtained from Egypt. Subm by A R David, Manchester Mus, Univ Manchester, England. Body material and wrapping bandages were dated not only to determine age of body, but also to determine whether body had been re-wrapped substantially later than death of individual. Comment: ${ }^{14} \mathrm{C}$ ages found by Manchester lab for components of mummy are $2690 \pm 180$ for right scapula bone collagen, $2740 \pm 170$ for left scapula bone collagen, $1510 \pm 130$ for outer bandage, and $1640 \pm 140$ for part 4 bandage (A R David, pers commun). Manchester lab results indicated either that bones contained carbon of fossil origin, perhaps bitumen from Dead Sea area, used in mummification process, or, more likely, that body was wrapped or re-wrapped substantially later than death of individual. However, La Jolla results, below, further confused resolution of problem.

\section{LJ-4915. Manchester $2290 \pm 40$}

Soft tissue (skin) from left humerus. Pretreated only with dilute Calibration: 580 to $410 \mathrm{BC}$ (580 to 180$)$.

\section{LJ-4995. Manchester Mummy 1770, wrapping $2920 \pm 60$ bandages $\delta^{13} \mathrm{C}=-25.7 \%$ o}

Wrapping bandages from over right side, arm, and chest. Pretreated only with dilute HCl. Calibration: 1340 to $1170 \mathrm{BC}$ (1350 to 895).

\section{LJ-4996. Manchester Mummy 1770, wrapping $2130 \pm 60$ bandages $\quad \delta^{1 .} \mathrm{C}=-26.2 \%$}

Chest bandages from beneath cantannage chest cover. Pretreated only with dilute HCl. Calibration: 375 to 180 BC (390 to 1). 


\section{Terqa series}

Syria

Ten charcoal samples from ancient Terqa (modern Ashara), on edge of Euphrates R, E Syria $\left(34^{\circ} 55^{\prime} \mathrm{N}, 40^{\circ} 30^{\prime} \mathrm{S}\right)$. Samples 1 to 7 coll from slopes of moat outside city wall and floor deposit just inside city wall of Terqa, major center of civilization from ca $5000 \mathrm{yr}$ BP. Samples 8 and 9 coll from floor deposits inside room of Old Babylonian private house at Terqa, together with small archive of cuneiform tablets. Sample 10 coll from floor deposits in Temple of Ninkarrak, stratigraphically comparable to Samples 8 and 9. Coll Oct and Nov 1978 by David Berry and Maryse Gaborit, both Univ California, Los Angeles; subm by Giorgio Buccellati, Inst Archaeol, Univ California, Los Angeles. Comment (GB): on typologic and stratigraphic grounds, construction of city wall assigned to early part of third millennium вс. Three phases of construction of wall formed massive defensive system-ca $20 \mathrm{~m}$ of solid mud brick, with protective base in stone, for perimeter of ca $1.6 \mathrm{~km}$. This is largest defensive system found in Syria and Mesopotamia, with momentous implications for history of early development of urban civilization.

\section{LJ-4821. Terqa, TQ4-S284, Sample 1}

$4210 \pm 80$

Charcoal from ca $4 \mathrm{~m}$ below surface, just above virgin soil at base of first phase of city wall. From same loc as TQ4-S283, L J-5052, below, but from lower level. Comment (GB): expected date, 2800 to 2700 BC. Calibration: $2910 \mathrm{BC}(3150$ to 2555$)$.

\section{LJ-5052. Terqa, TQ4-S283, Sample 2}

$$
4110 \pm 70
$$

Charcoal (reasonably pure, but finely dispersed) from ca $3.5 \mathrm{~m}$ below surface, $50 \mathrm{~cm}$ above virgin soil at base of first phase of city wall. Comment (GB): expected date, 2800 to 2700 BC. Comment: no asphaltenes present. See Comment for LJ-5031, below. Calibration: 2880 to 2800 BC (2900 to 2425).

\section{LJ-5053. Terqa, TQ4-S311, Sample 3}

$4660 \pm 80$

Charcoal from just above base of first phase of city wall, from slightly higher stratigraphic position than LJ-4821 and -5052, above. Comment (GB): expected date, 2800 to 2600 BC. Calibration: 3490 вC (3760 to 3155).

\section{LJ-4822. Terqa, TQ4-S314, Sample 4}

$4870 \pm 90$

Finely divided charcoal from ca $4 \mathrm{~m}$ below surface, $50 \mathrm{~cm}$ above virgin soil, just outside second phase of city wall. Comment (GB): expected date, 2600 to 2500 BC. Calibration: 3780 to 3660 BC (3885 to 3375$)$.

\section{LJ-5031. Terqa, TQ4-S313, Sample 5}

$28,800 \pm 1300$ surface, $50 \mathrm{~cm}$ above virgin soil, further out from second phase of city wall 
than LJ-4822, above; after certain time that second phase of city wall had been in use, under third phase of city wall. Comment (GB): expected date, 2500 to 2400 BC. Comment: organic geochemical analysis of additional material from same sample clearly indicated contamination of charcoal with ancient asphalt (Venkatesan $e t$ al, 1982). Asphalt sample from goblet from Terqa area has same n-alkane and triterpenoidal distributions as this sample and LJ-4823 (TQ4-S267), below. H/C ratio and $\delta^{13} \mathrm{C}$ for asphaltenes from goblet asphalt and TQ4-S313 and TQ4-S267 also agree. Any Terqa charcoal samples that gave anomalously old ${ }^{14} \mathrm{C}$ ages may be assumed to have contained some asphaltic material. See LJ-5362, below.

\section{LJ-5362. Terqa, TQ4-S313, extracted, Sample 6 \\ $27,700 \pm 1400$ $\delta^{13} C=-28.5 \%$}

Same material as LJ-5031, above, except Soxhlet-extracted successively with methanol and toluene/methanol $(3: 7 \mathrm{v} / \mathrm{v})$ for $100 \mathrm{hr}$. Comment: age is statistically same as that of unextracted sample (LJ-5031, above), which suggests that great age is largely due to insoluble pyrobitumen that could have come from asphalt (Venkatesan et al, 1982).

\section{LJ-4823. Terqa, TQ4-S267, Sample 7}

$\mathbf{5 7 0 0} \pm \mathbf{1 0 0}$

Charcoal from ca $4 \mathrm{~m}$ below surface, $50 \mathrm{~cm}$ above virgin soil, just outside base of third phase of city wall. Comment (GB): expected date, 2400 to 2300 BC. Comment: sample contaminated with asphaltenes (ca $17 \%$ asphaltene concentration found in TQ4-S313) and with hexane-soluble lipids (ca 10\% concentration found in TQ4-S313) (Venkatesan et al, 1982). Calibration: 4730 to 4570 вс (4885 to 4405 ).

\section{LJ-4824. Terqa, TQ4-S263, Sample 8}

$$
\mathbf{3 4 6 0} \pm \mathbf{7 0}
$$
pottery sherds, from later occupation of site than all samples above. Comment (GB): on second millennium BC samples: my original suggestion of chronologic range between 1700 and 1500 BC was based on preliminary reading of tablets and acceptance of middle chronology. Subsequent study of tablets has narrowed possible range to ca 1720 to $1680 \mathrm{BC}$ according to middle chronology. On the other hand, an important study (Huber, 1982) has proposed strong new astronomical arguments in favor of high chronology; if so, range for tablets accompanying Terqa samples would be ca 1780 to $1750 \mathrm{BC}$ - a date which is generally more in keeping with ${ }^{14} \mathrm{C}$ determinations. Calibration: 1930 to 1770 вс (1970 to 1665).

\section{LJ-5054. Terqa, TQ4-S162, Sample $9 \quad \delta^{15} \mathrm{C}=-25.7 \%$}

Charcoal from same provenience as LJ-4824, above. Calibration: 1920 to $1740 \mathrm{BC}$ (1980 to 1555$)$.

LJ-5055. Terqa, TQ4-S262, Sample 10

$\mathbf{3 5 1 0} \pm \mathbf{8 0}$

Charcoal found in public building adjacent to private house from 
which LJ-4824 and -5054, above, were obtained, but from higher level. Calibration: 1960 to 1850 вс (2150 to 1665 ).

\section{Scaloria Cave series}

\section{Italy}

Thirteen charcoal samples from Scaloria Cave, $2 \mathrm{~km} \mathrm{NW}$ of Manfredonia, Puglia, SE Italy $\left(41^{\circ} 39^{\prime} \mathrm{N}, 15^{\circ} 54^{\prime} \mathrm{E}\right)$. Samples recovered deep in cave which contains Neolithic burial site and Mesolithic camp. Coll by S M M Winn, Univ Southern Mississippi, Hattiesburg, and Marija Gimbutas, Inst Archaeol, Univ California, Los Angeles; subm by Marija Gimbutas.

\section{LJ-4650. Scaloria Cave, TR1/L8}

$6490 \pm 140$

Charcoal from Trench 1, Level 8, on and around human skull which is being studied for pathology. Coll Aug 1978. Date important for establishing horizontal stratigraphy, grave types, chronologic use of cemetery, Neolithic sequence, etc. Calibration: 5520 to 5450 BC (5730 to 5110 ).

\section{LJ-4651. Scaloria Cave, TR1/L8}

$6330 \pm 90$

Charcoal from Trench 1 , Level 8 , in vicinity of skull mentioned above; charcoal is probably from same source as LJ-4650. Stratigraphy sealed below calcareous level, meaning no possible admixture of later materials. Coll Aug 1978. Sample important for establishing use of cemetery in cave for Scaloria period. Calibration: 5340 to 5250 BC (5545 to 5020).

\section{LJ-4649. Scaloria Cave, TR3/L3}

$6720 \pm 100$

Charcoal from Trench 3, Level 3, 20 to $30 \mathrm{~cm}$ depth in pit burial, found near mandible. Coll Aug 1978. Important chronologic implications for early Neolithic in Italy; date needed to establish sequence in cemetery and habitation outside cemetery. Calibration: 5650 to 5600 BC (5940 to $5315)$.

\section{LJ-4983. Scaloria Cave, TR5/L3}

$6120 \pm 80$

Charcoal from Trench 5, Level 3, from Neolithic period. Coll Aug 1979. Stratigraphy and assoc ceramics (eg, Ripoli-style painted ware) indicate latest period (Late Scaloria) of habitation in cave. Calibration: 5130 to 5020 вС (5295 to 4890$)$.

\section{LJ-5095. Scaloria Cave, TR6/L4}

$$
6400 \pm 80
$$

Charcoal from Trench 6, North Level 4; habitation debris from Neolithic period. Coll Aug 1979. Calibration: 5500 to 5330 BC (5605 to 5080).

\section{LJ-5096. Scaloria Cave, TR6/L6 \& 7}

$$
6290 \pm 80
$$

Charcoal from Trench 6, South, Levels 6 and 7, near grave, from Neolithic period. Coll Aug 1979. Calibration: 5340 to 5250 BC (5505 to 4980). 
LJ-5097. Scaloria Cave, TR7/L1

$$
6290 \pm 90
$$
apparently reserved for cemetery usage. No habitation levels present. Neolithic period. Coll Aug 1979. Calibration: 5340 to 5250 BC (5505 to 4980).

\section{LJ-4980. Scaloria Cave, TR10}

$$
\begin{array}{r}
\mathbf{6 4 1 0} \pm \mathbf{1 5 0} \\
\delta^{13} C=-24.7 \% \text {. }
\end{array}
$$

Charcoal from Trench 10, from level of Neolithic ritual burials. Found with boar tusk pendants and long flint blades. Coll Sept 1979. Calibration: 5500 to $5330 \mathrm{BC}(5650$ to 5055$)$.

\section{LJ-4981. Scaloria Cave, TR10/L4}

$6530 \pm 260$ lithic ritual burials. Coll Sept 1979. Dates floor of ritual mass burial. Calibration: 5520 to 5450 вс (5895 to 5010$)$.

\section{LJ-4982. Scaloria Cave, TR8/L3}

$9560 \pm 140$

Charcoal from Trench 8, Level 3, from Upper Palaeolithic/Mesolithic period. From area with concentration of animal bones and teeth; some lithics present. Coll Aug 1979.

\section{LJ-5098. Scaloria Cave, TR8/LA}

$9030 \pm 120$

Charcoal from Trench $8 / 8 \mathrm{~N}$, Level 4, from Upper Palaeolithic/Mesolithic period. From feature of arranged stones, splintered bone, and burned area, suggesting fire pit. Coll Aug 1979.

\section{LJ-4978. Scaloria Cave, TR8/L8}

$10,790 \pm 210$ $\delta^{13} \mathrm{C}=-24.0 \%$

Charcoal from Trench 8, Level 8, from Upper Palaeolithic/Mesolithic period. From soil feature containing abundant lithics and bones. Coll Sept 1979.

\section{LJ-4979. Scaloria Cave, TR8/L9}

$11,040 \pm 190$

Charcoal from Trench 8, Level 9, from Upper Palaeolithic/ 4 oso lithic period. From yellowish, sandy soil containing numerous lithic artifacts. Coll Sept 1979.

\section{Romania series}

\section{Romania}

Three wood charcoal samples from Celei-Sucidava, Bez Oltenien. Samples subm by and previously dated by Günther Kohl, Akad Wissenschaften DDR, Zentralinst f Alte Geschicte \& Archäol, East Berlin. Bln dates below are by pers commun to $\mathrm{H}$ E Suess. Bln lab thought that their ${ }^{14} \mathrm{C}$ ages were 300 to $400 \mathrm{yr}$ too young, but LJ results were slightly younger still. 
LJ-5232. Celei-Sucidava \# 1

$4170 \pm 110$

Charcoal Sample \# 1 from Celei-Sucidava, Haüs 1 of Celei-Kirltni. Previously dated at $4225 \pm 60$ (Bln-2014). Calibration: 2900 to $2820 \mathrm{BC}$ (3035 to 2425$)$.

LJ-5231. Celei-Sucidava \#2

$4030 \pm 90$

Charcoal Sample \#2 from Celei-Sucidava, Haüs 2 of Celei-Kirltni. Sample contained many fine rootlets. Previously dated at $4135 \pm 45$ (Bln2015). Calibration: 2800 to 2560 вс (2890 to 2315$)$.

\section{LJ-5233. Celei-Sucidava \#3}

$4160 \pm 90$

Charcoal Sample \#3 from Celei-Sucidava, Haüs 7 of Celei-Kirltni. Previously dated at $4335 \pm 45$ (Bln-2016). Calibration: 2890 to $2820 \mathrm{BC}$ (3030 to 2425).

\section{LJ-5262. Ganovce}

Wood (15 to 20 tree rings) from Ganovce, Bez Poprad/Seovukei, from Brünnen of Bronze age Ottoman culture. Subm by Günther Kohl. Previously dated at $3445 \pm 40$ (Bln-2011). Calibration: 1940 to 1830 вс (2145 to $1660)$.

\section{West Anatolia series}

\section{Turkey}

Four charcoal samples from Demirci Hüyük, early Bronze age site in W Anatolia. Site has $9.5 \mathrm{~m}$ of deposits with 17 building phases. Subm by Günther Kohl.

\section{LJ-5237. Demirci Hüyuik, K8.1227}

$4250 \pm 40$

Charcoal from Phase $\mathrm{H}$ of early Bronze age at site. Historic date of $\mathrm{ca}$ 3000 to 2500 BC. Calibration: 2970 to 2910 BC (3145 to 2660).

\section{LJ-5235. Demirci Hüiyük, L9.123}

$$
4190 \pm 80
$$

Charcoal from Phase H of early Bronze age at site. Historic date of 3000 to 2500 BC. Calibration: 2900 to 2850 BC (3135 to 2440).

\section{LJ-5238. Demirci Hüyük, K9.Z.65}

$4230 \pm 60$

Charcoal from Phase E2 of early Bronze age at site. Historic date of ca 3400 to 2700 BC. Calibration: 2950 to 2900 вс (3045 to 2655).

\section{LJ-5236. Demirci Hüyüik, E8.332}

$3910 \pm 90$

Charcoal from Phase El of early Bronze age at site Historic date of ca 3400 to 2700 BC. Calibration: 2480 to 2400 BC (2765 to 2145).

\section{LJ-5234. Norsuntepe, E Anatolia}

$4280 \pm 120$

$\delta^{13} \mathrm{C}=-25.4 \%$

Charcoal from Norsuntepe, early Bronze Age I site in E Anatolia. 
Subm by Günther Kohl. Expected to date from end of 4th or 1st half of 3rd millennium BC. Calibration: 3100 to 2920 BC (3350 to 2650).

GEOLOGIC SAMPLES

Terrestrial_California

\section{LJ-5670. San Emigdio Mts}

Small snail shells picked from lake sediments in lake bed exposure between Lake of the Woods and Pine Mountain Club, on Mil Potrero Hwy, San Emigdio Mts, on Sawmill Mountain USGS 7.5'Quad (34 $51^{\prime} \mathrm{N}$, $119^{\circ} 08^{\prime} \mathrm{W}$ ). From $4 \mathrm{~m}$ below surface. Coll Feb 1980 by Thom Davis; subm by Thom Davis and E A Keller, Dept Geol Sci, Univ California, Santa Barbara.

\section{LJ-5669. Coyote Lake}

$12,900 \pm 1800$ from Sec 11, TIN, R7E on Twentynine Palms USGS 15' Quad (34 $12^{\prime} \mathrm{N}$, $\left.116^{\circ} 14^{\prime} \mathrm{W}\right)$. From $2 \mathrm{~m}$ below surface. Coll July 1980 by Thom Davis and Ernest Duebendorfer; subm by Thom Davis and E A Keller. Dated for age control on magnetic secular variation curve for Holocene.

\section{La Nación Fault series}

Seven soil and caliche samples measured to date last movement of La Nación fault; all samples coll from between 59 th and 61 st $\mathrm{St}$, between Division and Newcastle St, San Diego (ca $32^{\circ} 42^{\prime} \mathrm{N}, 117^{\circ} 04^{\prime} \mathrm{W}$, exact coordinates given below). Two other samples from site contained $<0.015 \%$ organic carbon (by weight) in soil, providing two samples too small for dating. Coll and subm by Wendell Gayman, Sea Sci Services, San Diego. Interpretation of dates is questionable because of type of materials dated; see Gayman (1979). No chemical pretreatment.

\section{LJ-4729. La Nación Fault, Sample 5}

$20,400 \pm 400$

Inorganic carbon from mixe dug $2 \mathrm{~m}$ into alluvium and near-surface formations $\left.117^{\circ} 04^{\prime} 13^{\prime \prime} \mathrm{W}\right)$. Sample coll at $1.4 \mathrm{~m}$ depth in $\operatorname{Tr} \mathrm{T}-27$, from subsoil in top of Otay Formation, ca $5.5 \mathrm{~m}$ E of fault. Coll Feb 1979.

\section{LJ-4730. La Nación Fault, Sample 28}

$29,800 \pm 1100$

$\delta^{13} \mathrm{C}=-8.3 \%$

Inorganic carbon from mixed caliche and clay from backhoe trench dug $2.1 \mathrm{~m}$ deep at site $\left(32^{\circ} 41^{\prime} 50^{\prime \prime} \mathrm{N}, 117^{\circ} 04^{\prime} 10^{\prime \prime} \mathrm{W}\right)$. Sample coll from ca $1.1 \mathrm{~m}$ depth at $\mathrm{W}$ end of $\operatorname{Tr} \mathrm{T}-34$, from subsoil overlying Pliocene San Diego Formation, ca $6 \mathrm{~m}$ W of fault. Coll Feb 1979.

\section{LJ-4745. La Nación Fault, Sample 45}

$18,800 \pm 600$ $\delta^{13} \mathrm{C}=-24.3 \%$

Organic carbon from carbonaceous soil from Tr T-38 dug $5.5 \mathrm{~m}$ into alluvium and near-surface formations at site $\left(32^{\circ} 41^{\prime} 52^{\prime \prime} \mathrm{N}, 117^{\circ} 04^{\prime} 13^{\prime \prime}\right.$ 
W). Sample coll from depth 2.1 to $2.4 \mathrm{~m}$ below surface. Soil contained $0.24 \%$ organic carbon by weight. Coll Mar 1979 .

\section{LJ-4746. La Nación Fault, Sample 41}

$\mathbf{3 0 , 3 0 0} \pm \mathbf{1 2 0 0}$

Organic carbon from carbonaceous soil from Tr T-38 dug $5.5 \mathrm{~m}$ into alluvium and near-surface formations at site $\left(32^{\circ} 41^{\prime} 52^{\prime \prime} \mathrm{N}, 117^{\circ} 04^{\prime} 13^{\prime \prime}\right.$ W). Sample coll from depth of 1.8 to $2.1 \mathrm{~m}$ below ground surface. Soil contained 1.4\% organic carbon by weight. Coll Mar 1979.

\section{LJ-4747. La Nación Fault, Sample 46}

$19,800 \pm 1000$

Organic carbon from soil with charcoal fractions (to $2 \mathrm{~cm}$ size) from $\operatorname{Tr}$ T-38 dug $5.5 \mathrm{~m}$ into alluvium and near-surface formations at site $\left(32^{\circ}\right.$ $\left.41^{\prime} 52^{\prime \prime} \mathrm{N}, 117^{\circ} 04^{\prime} 13^{\prime \prime} \mathrm{W}\right)$. Sample coll from ca 1.5 to $1.8 \mathrm{~m}$ below ground surface. Sample contained $0.22 \%$ organic carbon by weight. Coll Mar 1979.

\section{LJ-4748. La Nación Fault, Sample 29}

$14,300 \pm 300$

Organic carbon from carbonaceous clay (hard, dry, dark lumps) found at Sta 74 in Tr T-32, ca $1.5 \mathrm{~m}$ below top of trench dug $3.7 \mathrm{~m}$ deep by backhoe at site $\left(32^{\circ} 41^{\prime} 52^{\prime \prime} \mathrm{N}, 117^{\circ} 04^{\prime} 10^{\prime \prime} \mathrm{W}\right)$. Soil represented thick sec of alluvium, probably overlying Otay Formation. Sample may have come from 9 to $15 \mathrm{~m}$ E of fault; exact location of fault was not determined. Sample contained $0.18 \%$ organic carbon by weight. Coll Feb 1979.

\section{LJ-4749. La Nación Fault, Sample 10}

$5220 \pm 130$

Organic carbon from dark brown clayey sand taken from depth $1.1 \mathrm{~m}$ in $\operatorname{Tr} \mathrm{T}-28 \mathrm{~A}$ at site $\left(32^{\circ} 41^{\prime} 57^{\prime \prime} \mathrm{N}, 117^{\circ} 04^{\prime} 10^{\prime \prime} \mathrm{W}\right)$. Soil sample overlay Miocene Otay Formation, from ca $34 \mathrm{~m} \mathrm{E}$ of fault. Sample contained $0.60 \%$ organic carbon by weight. Coll Feb 1979. Calibration: 4120 to 4000 BC (4405 to 3680$)$.

\section{Oceanographic_Pacific Ocean}

\section{Ontong Java Plateau marine sediment series}

Fourteen inorganic carbon samples from deep-sea sediment in W equatorial Pacific Ocean. These samples from top and flanks of Ontong Java Plateau, N of Soloman Is. and ENE of New Guinea, were coll as box cores in Apr-May 1975 during Leg 9 of Eurydice Expedition of Scripps Inst Oceanog on track from Guam, Mariana Is., to Majuro, Marshall Is. Coring device obtained samples of $50 \mathrm{~cm} \mathrm{sq}$ and 30 to $45 \mathrm{~cm}$ deep. Cores were sub-sampled and analyzed for several physical properties, weight percent $\mathrm{CaCO}_{3}$, and preservation and sedimentation rates (Johnson, Hamilton, \& Berger, 1977; Berger \& Killingley, 1982). Samples reported here were taken from top layer of seven box cores; for each sample, two inorganic fractions were dated: a "bulk" fraction consisting of full range of particle sizes and "coarse" fraction consisting only of particles $>62 \mu$ diam. Subm by W H Berger, Scripps Inst Oceanog, Univ California, San Diego, 
La Jolla. Data presented in table 1, below, are continuation of series begun by Linick (1979) with data from 20 bulk samples. Estimated $\delta^{13} \mathbf{C}$ of $0.0 \%$ was used in calculating all apparent ages given below. Comment: comparisons to previous measurements pub in R, 1979, v 21, p 197-198, are as follows: Core $120 / 1$ to $5 \mathrm{~cm} / 3940 \pm 100(\mathrm{LJ}-3879)$, Core $123 / 1$ to $5 \mathrm{~cm} / 3390 \pm 80(\mathrm{LJ}-3885)$, Core $139 / 1$ to $5 \mathrm{~cm} / 5590 \pm 130(\mathrm{~L} \mathrm{~J}-4070)$, and Core $141 / 1$ to $5 \mathrm{~cm} / 7510 \pm 100$ (L J-4073). Comparisons to previous measurements from Peng, Broecker, and Berger (1979) are as follows: Core $92 / 0$ to $2 \mathrm{~cm} / 4230 \pm 240$ and Core $92 / 2$ to $4 \mathrm{~cm} / 4240 \pm 180$. Comparisons to previous measurements by Univ Miami as quoted by Berger and Killingley (1982) are as follows: Core $112 / 1$ to $5 \mathrm{~cm} / 4340 \pm 70$ and Core $128 / 1$ to $5 \mathrm{~cm} / 4015 \pm 80$. In each of seven cores listed here, coarse fraction gave greater apparent age than bulk fraction, showing effect of better preservation of larger particle sizes relative to re-dissolution.

TABLE 1

Ontong Java Plateau marine sediment series

\begin{tabular}{|c|c|c|c|c|c|c|c|}
\hline LJ no. & $\begin{array}{c}\text { Box } \\
\text { core no. }\end{array}$ & Lat & Long & $\begin{array}{c}\text { Water } \\
\text { depth (m) }\end{array}$ & $\begin{array}{l}\text { Depth in } \\
\text { core }(\mathrm{cm})\end{array}$ & $\begin{array}{l}\text { Bulk/ } \\
\text { coarse }\end{array}$ & Age \\
\hline-5584 & 92 & $2^{\circ} 13.5^{\prime} \mathrm{S}$ & $156^{\circ} 59.9^{\prime} \mathrm{E}$ & 1598 & $0-3$ & Bulk & $4410 \pm 130$ \\
\hline-5585 & 92 & $2^{\circ} 13.5^{\prime} \mathrm{S}$ & $156^{\circ} 59.9^{\prime} \mathrm{E}$ & 1598 & $0-3$ & Coarse & $4780 \pm 120$ \\
\hline-5586 & 112 & $1^{\circ} 37.5^{\prime} \mathrm{S}$ & $159^{\circ} 14.1^{\prime} \mathrm{E}$ & 2169 & $0-4$ & Bulk & $4060 \pm 110$ \\
\hline-5587 & 112 & $1^{\circ} 37.5^{\prime} \mathrm{S}$ & $159^{\circ} 14.1^{\prime} \mathbf{E}$ & 2169 & $0-4$ & Coarse & $4550 \pm 100$ \\
\hline-5636 & 120 & $0^{\circ} 01.0^{\prime} \mathrm{S}$ & $158^{\circ} 41.6^{\prime} \mathbf{E}$ & 2247 & $0-3$ & Bulk & $5070 \pm 120$ \\
\hline-5635 & 120 & $0^{\circ} 01.0^{\prime} \mathrm{S}$ & $158^{\circ} 41.6^{\prime} \mathbf{E}$ & 2247 & $0-3$ & Coarse & $5600 \pm 100$ \\
\hline-5613 & 123 & $0^{\circ} 01.3^{\prime} \mathrm{S}$ & $160^{\circ} 24.9^{\prime} \mathrm{E}$ & 2948 & $1-6$ & Bulk & $3250 \pm 100$ \\
\hline-5614 & 123 & $0^{\circ} 01.3^{\prime} \mathrm{S}$ & $160^{\circ} 24.9^{\prime} \mathbf{E}$ & 2948 & $1-6$ & Coarse & $3550 \pm 100$ \\
\hline-5602 & 128 & $0^{\circ} 00.3^{\prime} \mathrm{S}$ & $161 \circ 25.6^{\prime} \mathrm{E}$ & 3732 & $1-6$ & Bulk & $4010 \pm 110$ \\
\hline-5603 & 128 & $0^{\circ} 00.3^{\prime} \mathrm{S}$ & $161^{\circ} 25.6^{\prime} \mathrm{E}$ & 3732 & 1-6 & Coarse & $4720 \pm 90$ \\
\hline-5634 & 139 & $1^{\circ} 21.7^{\prime} \mathrm{N}$ & $162^{\circ} 23.6^{\prime} \mathrm{E}$ & 4118 & $0.5-5$ & Bulk & $5400 \pm 120$ \\
\hline-5633 & 139 & $1 \circ 21.7 \cdot \mathrm{N}$ & $162^{\circ} 23.6^{\prime} \mathbf{E}$ & 4118 & $0.5-5$ & Coarse & $6530 \pm 110$ \\
\hline-5615 & 141 & $2^{\circ} 21.7^{\prime} \mathrm{N}$ & $163^{\circ} 42.4^{\prime} \mathbf{E}$ & 4324 & $0.5-5$ & Bulk & $7090 \pm 190$ \\
\hline-5616 & 141 & $2^{\circ} 21.7 \cdot \mathrm{N}$ & $163^{\circ} 42.4^{\prime} \mathbf{E}$ & 4324 & $0.5-5$ & Conrse & $9260 \pm 120$ \\
\hline
\end{tabular}

\section{Pleiades sediment series}

Five deep-sea sediment inorganic carbon samples from under E equatorial Pacific Ocean. These samples were coll as box cores in July-Aug 1976 during Leg 3 of Pleiades Expedition of Scripps Inst Oceanog on track from Balboa, Canal Zone, to Honolulu, Hawaii. Subm by R C Finkel and W H Berger. For discussion of results, see Berger and Killingley (1982). Data are presented in table 2, below. Comment: comparisons to previous measurements on these cores by $\mathrm{L}, \mathrm{J}$ lab pub in Berger and Killingley (1982) are as follows: Core 72: 0 to $3 \mathrm{~cm} / 3990 \pm 70$ (L J-4518), 3 to $5 \mathrm{~cm} /$ $4220 \pm 110(\mathrm{LJ}-4519), 5$ to $7 \mathrm{~cm} / 4060 \pm 80,10$ to $12 \mathrm{~cm} / 5260 \pm 90,14$ to $16 \mathrm{~cm} / 5640 \pm 70,18$ to $20 \mathrm{~cm} / 6830 \pm 80(\mathrm{~L} \mathrm{~J}-4520), 34$ to $36 \mathrm{~cm} / 12,570 \pm$ $180(\mathrm{LJ}-452 \mathrm{l})$. Core $74: 1$ to $3 \mathrm{~cm} / 4360 \pm 90,7$ to $9 \mathrm{~cm} / 4520 \pm 70,18$ to $20 \mathrm{~cm} / 7670 \pm 110$. Dated as part of study of ${ }^{14} \mathrm{C}$ sedimentation rates and benthic mixing suggesting that patterns of mixed layer ages, sedimentation rates, and mixed layer thickness were controlled by gradients of car- 
bonate dissolution and fertility and by small-scale redeposition processes (Berger \& Killingley, 1982).

TABLE 2

Pleiades sediment series

\begin{tabular}{|c|c|c|c|c|c|c|c|}
\hline LJ no. & $\begin{array}{c}\text { Box } \\
\text { core no. }\end{array}$ & Lat & Long & $\begin{array}{c}\text { Water } \\
\text { depth (m) }\end{array}$ & $\begin{array}{l}\text { Depth in } \\
\text { core }(\mathrm{cm})\end{array}$ & $\delta^{13} \mathrm{C} / 00$ & Age \\
\hline-4973 & $72-3$ & $1^{\circ} 00.8^{\prime} \mathrm{N}$ & $109^{\circ} 15.6^{\prime} \mathrm{W}$ & 3626 & $8-10$ & +0.5 & $4430 \pm 70$ \\
\hline-4974 & $72-3$ & $1^{\circ} 00.8^{\prime} \mathrm{N}$ & $109^{\circ} 15.6^{\prime} \mathrm{W}$ & 3626 & $20-22$ & +0.4 & $7250 \pm 100$ \\
\hline-4975 & $72-3$ & $1^{\circ} 00.8^{\prime} \mathrm{N}$ & $109^{\circ} 15.6^{\prime} \mathrm{W}$ & 3626 & $28-30$ & -0.2 & $10,430 \pm 140$ \\
\hline-4970 & $74-1$ & $1^{\circ} 00.1^{\prime} \mathrm{N}$ & $113^{\circ} 39.5^{\prime} \mathrm{W}$ & 3944 & $11-13$ & -0.3 & $4850 \pm 80$ \\
\hline-4972 & $74-1$ & $1^{\circ} 00.1^{\prime} \mathrm{N}$ & $113^{\circ} 39.5^{\prime} \mathrm{W}$ & 3944 & $28-80$ & 0.0 & $11,440 \pm 240$ \\
\hline
\end{tabular}

\section{Indopac-15 sediment series}

Eight samples of sedimentary organic carbon coll June 1977 on Indopac-15 Expedition of Scripps Inst Oceanog in central N Pacific Ocean $\left(28^{\circ}\right.$ $35.45^{\prime} \mathrm{N}, 155^{\circ} 30.39^{\prime} \mathrm{W}$ ). From Box Core 738, H-236, BC-3 in water depth $5584 \mathrm{~m}$. Area is extensive abyssal plain below low-productivity surface waters and underlain by red clay. Coll and subm by P M Williams, Scripps Inst Oceanog. Data are given in table 3, below. Comment (PMW): vertical distribution of organic ${ }^{14} \mathrm{C}$ in this core is similar to that found for Indopac-15 Core 638, H-22, coll June 1977 at $28^{\circ} 34.4^{\prime} \mathrm{N}, 155^{\circ} 30.3^{\prime} \mathrm{W}$, water depth $5780 \mathrm{~m}$. Previously pub results for Core 638 are as follows: (LJ-4054 and -4055: R, 1979, v 21, p 198; LJ-4221, -4222, -4223, and -4301: $\mathrm{R}, 1980$, v 22, p 1042): 0 to $3 \mathrm{~cm} / 10,700 \pm 600$ (LJ-4223), 5 to $7 \mathrm{~cm} / 16,000$ \pm 900 (LJ-4055), 7 to $9 \mathrm{~cm} / 18,500 \pm 900$ (LJ-4221), 11 to $13 \mathrm{~cm} / 20,300 \pm$ 2200 (LJ-4222), 13 to $15 \mathrm{~cm} />23,700$ (L -4301), 19 to $21 \mathrm{~cm} />22,000$ (LJ4054). For interpretation of data, see Williams et al (1978).

TABLE 3

Indopac-15 sediment series

\begin{tabular}{cccc}
\hline LJ no. & $\begin{array}{c}\text { Depth in } \\
\text { core }(\mathrm{cm})\end{array}$ & $\delta^{13} \mathrm{C} / \mathrm{ce}$ & Age \\
\hline-5067 & $0-0.5$ & -18.7 & $8000 \pm 600$ \\
-4695 & $1-2$ & -19.2 & $10,600 \pm 800$ \\
-5068 & $4-5$ & -18.1 & $12,400 \pm 1000$ \\
-5288 & $7-8$ & -17.5 & $14,000 \pm 600$ \\
-5069 & $9-10$ & -18.8 & $14,200 \pm 500$ \\
-5289 & $12-13$ & -19.3 & $31,000 \pm 4000$ \\
-5290 & $14-15$ & -19.0 & $31,000 \pm 4000$ \\
-4696 & $19-20$ & -21.3 & $>23,700$ \\
\hline
\end{tabular}

\section{LJ-5555. Pacific sediment}

$2800 \pm 120$

$\delta^{13} \mathrm{C}=-23.1 \%$

Organic fraction of Pacific sediment from piston core M-4-70, 6P $\left(32^{\circ}\right.$ $\left.09.1^{\prime} \mathrm{N}, 118^{\circ} \mathrm{W}\right)$. From 5 to $14 \mathrm{~cm}$ depth in core. Coll Mar 1970 and subm by R B Dunbar, Scripps Inst Oceanog. Comment: sample from 190 to $210 \mathrm{~cm}$ depth in same core gave age 14,000 \pm 1000 (LJ-4175: R, 1980, v 22, p 1042). 
GEOCHEMICAL SAMPLES

\section{Hydrothermal vent marine organism series}

Mussel, clam, and vestimentiferan tubeworm samples from Pacific Ocean areas around Galápagos and East Pacific Rise hydrothermal vents. Samples studied to find sources of dietary carbon of organisms living in vicinity of hydrothermal vent systems (Williams et al, 1981). Mussels (Mytilus $\mathrm{sp}$ ) are filter-feeders; vestimentiferan tubeworms (Riftia pachyptila) lack mouth organs and digestive tracks, and they apparently use organic carbon synthesized internally by symbiotic chemoautotrophs. Possible dietary carbon sources of filter feeders include sedimentary particulate organic carbon (POC) derived from dissolved inorganic carbon (DIOC) originally fixed near ocean surface, POC synthesized by bacteria chemoautotrophically from ambient bottom water DIOC, and POC synthesized chemoautotrophically from magmatic DIOC and/or magmatic methane. Samples subm by P M Williams.

\section{LJ-5059. Mussel, PW-HTG-1-80}

$$
\begin{array}{r}
\Delta=-\mathbf{2 2 8} \pm \mathbf{1 2} \% \\
\delta^{1 s} C=-32.8 \% \circ
\end{array}
$$

Tissue of mussel coll in peripheral area $8 \mathrm{~m}$ from Galápagos "Musselbed" vent plume $\left(0^{\circ} 47.89^{\prime} \mathrm{N}, 86^{\circ} 09.21^{\prime} \mathrm{W}\right)$. Water depth $2480 \mathrm{~m}$. Dry weight 1.6g. Coll Jan 1979 on Alvin dive 880 by K L Smith, Scripps Inst Oceanog.

\section{LJ-5060. Mussel, PW-HTG-2-80}

$$
\Delta=-\mathbf{2 6 3} \pm \mathbf{8} \%
$$

$$
\delta^{13} \mathrm{C}=-33.8 \%
$$

Tissue of mussel coll $1 \mathrm{~m}$ from Galápagos "Musselbed" vent plume $\left(0^{\circ} 47.89^{\prime} \mathrm{N}, 86^{\circ} 09.21^{\prime} \mathrm{W}\right)$. Water depth $2493 \mathrm{~m}$. Dry weight $2.7 \mathrm{~g}$. Coll Feb 1979 on Alvin dive 895 by K L Smith.

\section{LJ-5061. Mussel, PW-HTG-3-80}

$$
\Delta=-\mathbf{2 7 0} \pm \mathbf{6} \%
$$$$
\delta^{1 s} \mathrm{C}=-33.9 \%
$$

Tissue of mussel coll $1 \mathrm{~m}$ from Galápagos "Musselbed" vent plume $\left(0^{\circ} 47.89^{\prime} \mathrm{N}, 86^{\circ} 09.2 \mathrm{1}^{\prime} \mathrm{W}\right)$. Water depth $2493 \mathrm{~m}$. Dry weight $2.9 \mathrm{~g}$. Coll Jan 1979 on Alvin dive 880 by K L Smith.

\section{LJ-5182. Mussel, N991-103}

$$
\begin{gathered}
\Delta=-\mathbf{2 5 4} \pm \mathbf{6} \% \\
\delta^{1 s} C=+2.8 \%
\end{gathered}
$$

Shell of mussel coll $1 \mathrm{~m}$ from Galápagos "Musselbed" vent plume $\left(0^{\circ}\right.$ $\left.47.89^{\prime} \mathrm{N}, 86^{\circ} 09.21^{\prime} \mathrm{W}\right)$. Water depth $2490 \mathrm{~m}$. Dry weight $15 \mathrm{~g}$. Coll Dec 1979 on Alvin dive 991.

\section{LJ-5198. Tubeworm, PW-HTG-5-80}

$$
\Delta=-\mathbf{2 7 0} \pm \mathbf{2 0} \% \text { 。 }
$$$$
\delta^{1 s} \mathrm{C}=-10.9 \%
$$

Muscle of vestimentiferan tubeworm (Riftia pachyptila) coll in Galápagos “Garden of Eden" vent plume $\left(0^{\circ} 47.69^{\prime} \mathrm{N}, 86^{\circ} 07.74^{\prime} \mathrm{W}\right)$. Water depth $2518 \mathrm{~m}$. Dry weight $0.29 \mathrm{~g}$. Coll Dec 1979 on Alvin dive 993.

\section{LJ-5140. Clam, PW-HT21-1-80}

$$
\begin{gathered}
\Delta=-263 \pm 6 \% \\
\delta^{1 s} C=+3.1 \%
\end{gathered}
$$

Shell of clam coll from East Pacific Rise hydrothermal vent system $\left(20^{\circ} 50^{\prime} \mathrm{N}, 109^{\circ} 06^{\prime} \mathrm{W}\right)$. Water depth ca $2600 \mathrm{~m}$. Dry weight $7.6 \mathrm{~g}$. Coll Nov 1979 on Alvin dive 981. 


\section{North Pacific gyre marine organism series}

Six marine organism samples (rat-tail fish and amphipods) coll Aug 1979 on "Marianas 12" cruise of $R / V$ Thomas Washington, of Scripps Inst Oceanog. Samples coll in mid-central N Pacific gyre (ca $31^{\circ} \mathrm{N}, 159^{\circ}$ $\mathrm{W}$; exact locations given below). Subm by P M Williams.

\section{LJ-5091. Rat-tail fish, PW- ${ }^{14}$ C-E-79}

$$
\Delta=+66 \pm 10 \%
$$

$$
\delta^{13} \mathrm{C}=-19.3 \%
$$

Muscle of rat-tail fish (Coryphaenoides armatus) caught in net $716 \mathrm{~m}$ above bottom at Sta $186\left(30^{\circ} 57.6^{\prime} \mathrm{N}, 159^{\circ} 04.0^{\prime} \mathrm{W}\right)$. Bottom depth $5900 \mathrm{~m}$. Dry weight $2 \mathrm{~g}$.

\section{LJ-5092. Rat-tail fish, PW ${ }^{14}$ C-F-79}

$$
\begin{gathered}
\Delta=+85 \pm 15 \% \\
\delta^{13} C=-19.3 \% \text { o }
\end{gathered}
$$

Muscle of rat-tail fish (Coryphaenoides armatus) caught in net 3 to $5 \mathrm{~m}$ above bottom at Sta $186\left(30^{\circ} 57.6^{\prime} \mathrm{N}, 159^{\circ} 04.0^{\prime} \mathrm{W}\right)$. Bottom depth $5900 \mathrm{~m}$. Dry weight $1.3 \mathrm{~g}$.

\section{LJ-5093. Rat-tail fish, PW- ${ }^{14}$ C-G-79}

$$
\begin{array}{r}
\Delta=+62 \pm 17 \% \circ \\
\delta^{13} C=-19.0 \% \circ
\end{array}
$$

Muscle of rat-tail fish (Coryphaenoides armatus) caught in net $305 \mathrm{~m}$ above bottom at Sta $119\left(31^{\circ} 00.1^{\prime} \mathrm{N}, 159^{\circ} 16.9^{\prime} \mathrm{W}\right)$. Bottom depth $5809 \mathrm{~m}$. Dry weight $1.5 \mathrm{~g}$.

\section{LJ-5362. Amphipods, PW $-{ }^{14} \mathrm{C}-\mathrm{H}-79$}

$$
\Delta=+67 \pm 18 \%
$$
4.6 to $6.1 \mathrm{~m}$ above bottom at Sta $211\left(31^{\circ} 00.6^{\prime} \mathrm{N}, 158^{\circ} 56.7^{\prime} \mathrm{W}\right)$. Bottom depth $5867 \mathrm{~m}$. Fish were gutted before drying. Dry weight $1.4 \mathrm{~g}$.

\section{LJ-5363. Amphipods, PW- ${ }^{14}$ C-I-79}

$$
\Delta=+110 \pm \mathbf{8} \% \text { o }
$$

Two specimens of amphipod (Eurythenes sp) caught at two slightly different locations: 1) $716 \mathrm{~m}$ above bottom at Sta $147\left(31^{\circ} 02.2^{\prime} \mathrm{N}, 159^{\circ}\right.$ $\left.21.9^{\prime} \mathrm{W}\right)$, bottom depth $5789 \mathrm{~m}$; 2) $305 \mathrm{~m}$ above bottom at Sta $175\left(31^{\circ}\right.$ $\left.08.8^{\prime} \mathrm{N}, 159^{\circ} 21.9^{\prime} \mathrm{W}\right)$, bottom depth $5777 \mathrm{~m}$. Combined dry weight $1.8 \mathrm{~g}$.

\section{LJ-5364. Amphipod, PW- ${ }^{14}$ C-J-79}

$$
\begin{array}{r}
\Delta=+100 \pm \mathbf{9} \% o \\
\delta^{1 s} C=-21.4 \% \circ
\end{array}
$$

One specimen of amphipod (Eurythenes sp) caught $914 \mathrm{~m}$ above bottom at Sta $211\left(31^{\circ} 00.6^{\prime} \mathrm{N}, 158^{\circ} 56.7^{\prime} \mathrm{W}\right)$. Bottom depth $5867 \mathrm{~m}$. Dry weight $1.2 \mathrm{~g}$.

\section{Palm tree series}

\section{BOTANIC AND ATMOSPHERIC SAMPLES}

Three samples from palm tree (Cocos nucifera) grown near sea level near Aracaju, Sergipe state, NE Brazil (ca $\left.11^{\circ} 00^{\prime} \mathrm{S}, 37^{\circ} 01^{\prime} \mathrm{W}\right)$. Continuation of series from Linick (1980), who gave sample treatment details and interpretation of ${ }^{14} \mathrm{C}$ data. Samples analyzed to determine growth pattern of palm, which does not form annual rings. Subm by L H G Wiesberg, Chemistry Dept, Pontifícia Univ Católica, Rio de Janeiro, Brazil. Wiesberg and Linick (1983) discuss growth of palm. 


\section{LJ-4949. Palm, 10.4m, inside \\ $\Delta=-\mathbf{9} \pm \mathbf{4} \%$ c}

Wood taken from 0 to $4 \mathrm{~cm}$ from center of tree $10.4 \mathrm{~m}$ above ground.

LJ-4950. Palm, 10.4, outside

$\Delta=-\mathbf{7} \pm \mathbf{4} \%$

Wood taken from ca 0.5 to $2 \mathrm{~cm}$ in from bark $10.4 \mathrm{~m}$ above ground.

\section{LJ-4951. Palm, 9.4m, inside}

$\Delta=+\mathbf{1 3} \pm \mathbf{4} \%$

$\delta^{18} \mathrm{C}=-24.8 \%$

Wood taken from 0 to $4 \mathrm{~cm}$ from center of tree $9.4 \mathrm{~m}$ above ground. Comment: although this inside sample from $9.4 \mathrm{~m}$ contained less bomb ${ }^{14} \mathrm{C}$ than another inside sample from same height $(\Delta=+87 \pm 8 \%$, LJ-4304: R, 1980, v 22, p 1044), conclusions given by Linick (1980) are still valid; active vascular bundle may have been present more in LJ-4304 than in -4951 .

\section{Fruit series}

Two samples of unsweetened fruit preserves made from fruit grown in AD 1942. For comparison, values are $-19 \pm 2 \%$ for tree rings from 1941 and 1942 and $-23 \pm 2 \%$ for tree ring from 1943 (Stuiver, 1982).

\section{LJ-5517. Raspberries}

$$
\Delta=-\mathbf{2 7} \pm \mathbf{3} \%
$$

Raspberry preserves made in 1942 on Nantucket I., Massachusetts (ca $\left.41^{\circ} 15^{\prime} \mathrm{N}, 70^{\circ} 00^{\prime} \mathrm{W}\right)$.

\section{LJ-5518. Apples}

$$
\begin{aligned}
& \Delta=-\mathbf{2 0} \pm \mathbf{3} \% \\
& \delta^{13} C=-20.2 \%
\end{aligned}
$$

Apple preserves made in 1942, location unknown.

\section{Terrestrial vegetation and atmospheric $\mathrm{CO}_{2}$ series}

Several samples of vegetation grown in La Jolla, California, and Heidelberg, West Germany, in 1980 were analyzed to determine whether any geog differences existed and whether there was any difference in $\delta^{13} \mathrm{C}$-corrected $\Delta$ values between plants utilizing different photosynthetic pathways (C3 and C4). Samples of atmospheric $\mathrm{CO}_{2}$ were also coll by two methods at ground level outside La Jolla lab atop Mt Soledad. Samples below are arranged by date of colln. Vegetation samples coll by $\mathrm{H}$ E Suess; atmospheric $\mathrm{CO}_{2}$ samples coll by E M Druffel and T W Linick. Comment: no trends discernible, other than possible trend for samples coll later in summer of 1980 to have slightly higher activity than those coll earlier in year.

\section{LJ-5194. Fig, La Jolla}

$$
\Delta=+\mathbf{2 6 3} \pm \mathbf{6} \%
$$$$
\delta^{13} \mathrm{C}=-25.1 \% \text { 。 }
$$

Fruit of fig tree. Coll May 1980 at residence of H E Suess, La Jolla, near Univ California, San Diego.
LJ-5196. Wheat, Heidelberg
$\Delta=+\mathbf{2 6 0} \pm \mathbf{5} \% c$
Winter wheat. Coll June 1980 from Waldhilsbach, near Heidelberg. 
LJ-5197. Maize (corn), Heidelberg

$\Delta=+\mathbf{2 5 7} \pm \mathbf{5} \%$ o

$\delta^{1 s} \mathrm{C}=-12.4 \%$

Maize (corn). Coll June 1980 from Waldhilsbach, near Heidelberg.

\section{LJ-5209. Atmospheric CO $\mathrm{CO}_{2}$, La Jolla}

$$
\Delta=+253 \pm 11 \% \text { o }
$$

$\delta^{13} C=-20.5 \%$

Atmospheric $\mathrm{CO}_{2}$ coll outside La Jolla lab by bubbling air through $\mathrm{CO}_{2}$-absorber solution for $25 \mathrm{hr}$ on June 19 and 20, 1980. Absorber solution consisted of $454 \mathrm{~g} \mathrm{BaCl}_{2} \cdot 2 \mathrm{H}_{2} \mathrm{O}$ dissolved in $2668 \mathrm{~g}$ concentrated $\mathrm{NH}_{4} \mathrm{OH}$ solution. Air was bubbled through 3 absorber bottles, containing 700,400 , and $250 \mathrm{ml}$, sequentially, of absorber solution.

\section{LJ-5210. Atmospheric $\mathrm{CO}_{2}$, La Jolla}

$$
\begin{array}{r}
\Delta=+\mathbf{2 5 2} \pm \mathbf{1 4} \% \\
\delta^{13} C=-26.6 \%
\end{array}
$$

Atmospheric CO. coll outside La Jolla lab by blowing air from fan over tray containing $\mathrm{NH}_{4} \mathrm{OH} / \mathrm{BaCl}_{2}$ absorber solution for same $25 \mathrm{hr}$ as LJ-5209, above, on June 19 and 20, 1980.

\section{LJ-5193. Fig, La Jolla}

$$
\Delta=+\mathbf{2 7 3} \pm \mathbf{8} \%
$$$$
\delta^{13} \mathrm{C}=-25.4 \%
$$

Fruit of fig tree. Coll July 1980 at residence of H E Suess.

\section{L-5 195. Fig leaves, La Jolla}

$$
\begin{array}{r}
\Delta=+272 \pm 4 \% \\
\delta^{13} C=-28.0 \%
\end{array}
$$

Leaves of fig tree. Coll July 1980 at residence of H E Suess.

\section{LJ-5213. Atmospheric CO $\mathrm{CO}_{2}$, La Jolla}

$$
\begin{array}{r}
\Delta=+276 \pm 4 \% \\
\delta^{13} C=-25.4 \%
\end{array}
$$

Atmospheric $\mathrm{CO}_{2}$ coll outside La Jolla lab by blowing air from fan over tray containing $\mathrm{NH}_{4} \mathrm{OH} / \mathrm{BaCl}_{2}$ absorber solution for 5 days from Aug 28, 1980, to Sept 2, 1980.

\section{REIERENCES}

Berger, W H and Killingley, J S, 1982, Box cores from the equatorial Pacific: ${ }^{14} \mathrm{C}$ sedimentation rates and benthic mixing: Marine Geol, v 45, p 93-125.

Gayman, Wendell, 1979, Investigation of the age of Late Quaternary movements on the La Nación Fault, San Diego, California: Sea Sci Services tech rept, 12 p.

Huber, P J, 1982, Astronomical dating of Babylon I and Ur III, in Buccellati, Giorgio, ed, Occasional papers on the Near East, Monographic journals of the Near East: Undena Pubs, v 1, no. 4, 199 p.

Johnson, T C, Hamilton, E L, and Berger, W H, 1977, Physical properties of calcarcous ooze: control by dissolution at depth: Marine Geol, v 24, p 259-277.

Klein, Jeffrey, Lerman, J C, Damon, P E, and Ralph, E K, 1982, Calibration of radiocarbon dates: tables based on the consensus data of the Workshop on Calibrating the Radiccarbon Time Scale: Radiocarbon, v 24, p 103-150.

Linick, T W, 1977, La Jolla natural radiocarbon measurements VII: Radiocarbon, v 19. p $19-48$. p 186-202.

1980, La Jolla natural radiocarbon measurements IX: Radiocarbon, v 22, p 1034-1044

Peng, 'T-H, Broecker, W S, and Berger, W H, 1979, Rates of benthic mixing in deep sea sediment as determined by radioactive tracers: Quaternary Research, v 11, p 141. 149.

Stuiver, Minze, 1982, A high-precision calibration of the AI radiocarbon time scale: Radiocarbon, v 24, p 1-26. 
Suess, H E, 1979, A calibration table for conventional radiocarbon dates, in Berger, Rainer, and Suess, H E, eds, Radiocarbon dating, Internatl conf on radiocarbon dating, 9th, Proc: Berkeley/Los Angeles, Univ California Press, p 777.784.

Venkatesan, M I, Linick, T W, Suess, H E, and Buccellati, Giorgio, 1982, Asphalt in carbon-14-dated archaeological samples from Terqa, Syria: Nature, v 295, p 517-519.

Wiesberg, L H G and Linick, T W, 1983, The question of diffuse secondary growth of palm trees: Radiocarbon, v 25, p 803-809.

Williams, P M, Smith, K L, Druffel, E M, and Linick, T W, 1981, Dietary carbon sources of mussel and tubeworms from Galápagos hydrothermal vents determined from tissue ${ }^{14} \mathrm{C}$ activity: Nature, v 292, p 448-449.

Williams, P M, Stenhouse, M C, Druffel, E M, and Koide, M, 1978, Organic ${ }^{14} \mathrm{C}$ activity in an abyssal marine sediment: Nature, v 276, p 698-701. 